UNIVERSIDADE DE BRASÍLIA

PROGRAMA DE PÓS-GRADUAÇÃO EM AGRONOMIA

FACULDADE DE AGRONOMIA E MEDICINA VETERINÁRIA

\title{
EFEITOS DA REMOÇÃO DO PALHIÇO RESIDUAL NA CICLAGEM DE NUTRIENTES E NO DESEMPENHO AGRONÔMICO DA CANA DE AÇÚCAR
}

MATEUS COSTA COELHO

DISSERTAÇÃO DE MESTRADO EM AGRONOMIA

BRASÍLIA, DF

JUNHO 2015 


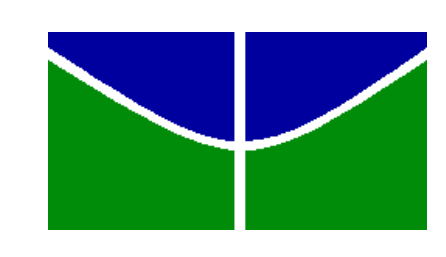

UNIVERSIDADE DE BRASÍLIA

FACULDADE DE AGRONOMIA E MEDICINA VETERINÁRIA PROGRAMA DE PÓS-GRADUAÇÃO EM AGRONOMIA

\title{
EFEITOS DA REMOÇÃO DO PALHIÇO RESIDUAL NA CICLAGEM DE NUTRIENTES E NO DESEMPENHO AGRONÔMICO DA CANA DE AÇÚCAR
}

\author{
MATEUS COSTA COELHO
}

ORIENTADOR: PROF. DR. MARCELO FAGIOLI

CO-ORIENTADOR: DRa. ARMINDA MOREIRA DE CARVALHO

DISSERTAÇÃO DE MESTRADO EM AGRONOMIA

PUBLICAÇÃO: 92/2015

BRASÍLIA/DF

JUNHO/2015 


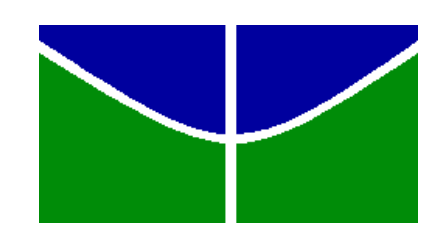

UNIVERSIDADE DE BRASÍLIA

FACULDADE DE AGRONOMIA E MEDICINA VETERINÁRIA

PROGRAMA DE PÓS-GRADUAÇÃO EM AGRONOMIA

\section{EFEITOS DA REMOÇÃO DO PALHIÇO RESIDUAL NA CICLAGEM DE NUTRIENTES E NO DESEMPENHO AGRONÔMICO DA CANA DE AÇÚCAR}

\section{MATEUS COSTA COELHO}

Dissertação de Mestrado submetida ao Programa de Pós-Graduação em Agronomia, como parte dos requisitos necessários à obtenção do grau de Mestre em Agronomia.

APROVADO POR:

\footnotetext{
Marcelo Fagioli

Professor Dr. / Universidade de Brasília / CPF 729.409.306-78 / mfagioli@unb.br Orientador
}

Thais Rodrigues Coser

Dra. / Embrapa / CPF 689.113.001-87 / thacoser@gmail.com

Examinador Externo

Thomaz Adolpho Rein

PhD. / Embrapa / CPF 027.990.018-07 / thomaz.rein@embrapa.br

Examinador Externo 


\section{FICHA CATALOGRÁFICA}

\begin{tabular}{|c|c|}
\hline \multirow{4}{*}{ C672e } & Coelho, Mateus Costa \\
\hline & $\begin{array}{l}\text { Efeitos da remoção do palhiço residual na ciclagem de } \\
\text { nutrientes e no desempenho agronômico da cana de açúcar } \\
\text { / } \\
\text { Mateus Costa Coelho; orientador Marcelo Fagioli; co- } \\
\text { orientadora Arminda Moreira de Carvalho. - Brasília, } 2015 \text {. } \\
\quad 53 \text { f. }\end{array}$ \\
\hline & $\begin{array}{l}\text { Dissertação (Mestrado - Mestrado em Agronomia) -- } \\
\text { Universidade de Brasília, } 2015 .\end{array}$ \\
\hline & $\begin{array}{l}\text { 1. Saccharum spp. 2. Palhiço. 3. Cana crua. } 4 \text {. } \\
\text { Decomposição. } 5 \text {. Ciclagem de nutrientes. I. Fagioli, } \\
\text { Marcelo, orient. Il. Carvalho, Arminda Moreira de, co-orient. } \\
\text { III. Título. }\end{array}$ \\
\hline
\end{tabular}

\section{REFERÊNCIA BIBLIOGRÁFICA}

COELHO, M. C. Efeitos da remoção do palhiço residual na ciclagem de nutrientes e no desempenho agronômico da cana de açúcar. Brasília: Faculdade de Agronomia e Medicina Veterinária, Universidade de Brasília, 2015, 53 f. Dissertação de Mestrado.

\section{CESSÃO DE DIREITOS}

NOME DO AUTOR: Mateus Costa Coelho

TÍTULO DA DISSERTAÇÃO: Efeitos da remoção do palhiço residual na ciclagem de nutrientes e no desempenho agronômico da cana de açúcar.

GRAU: Mestre

ANO: 2015

É concedida à Universidade de Brasília permissão para reproduzir cópias dessa dissertação de mestrado para única e exclusivamente propósitos acadêmicos e científicos. $\mathrm{O}$ autor reserva para si os outros direitos autorais, de publicação. Nenhuma parte desta dissertação de mestrado pode ser reproduzida sem a autorização por escrito do autor. Citações são estimuladas, desde que citada a fonte.

Nome: Mateus Costa Coelho

CPF: 017.164.831-58

Endereço: SQN 111, Bloco G, Ap. 202 - Asa Norte - Brasília/DF - CEP 70754-070

E-mail: ccoelhomateus@gmailcom

Telefone: (61) 8121-7313 


\section{AGRADECIMENTOS}

Primeiramente a Deus, por todas as bençãos que Ele tem derramado sobre mim.

Aos meus pais por todo o suporte necessário, até hoje, em todas as etapas da minha vida.

À minha companheira pela paciência durante esse curso.

À Universidade de Brasília e à Faculdade de Agronomia e Medicina Veterinária, junto a todo seu corpo docente, pela viabilização dessa oportunidade que me abrirá tantas portas.

Ao Professor Dr. Marcelo Fagioli, por todo o apoio e, principalmente, confiança e paciência.

A todo o corpo funcional da Embrapa Cerrados, pelo imenso apoio ao projeto de pesquisa, em especial aos pesquisadores Cláudio Franz, Marcos Carolino, Vinícius Buffon, Thomaz Rein, João de Deus, e Thais Coser.

À Dra. Arminda Moreira por todo o apoio e pela confiança como minha coorientadora.

Aos meus colegas de Embrapa, em especial à Juliana Hiromi, que muito me ajudou.

À Petrobrás e à FUNARBE pela viabilização financeira do projeto, junto à CAPES pelo auxílio financeiro durante o curso.

Aos demais que direta ou indiretamente contribuíram para a realização desse trabalho, muito obrigado. 


\section{RESUMO}

A colheita mecanizada sem queima da cana-de-açúcar gera um grande acúmulo de palhiço no campo. O objetivo do presente trabalho foi avaliar os efeitos de diferentes quantidades de palhiço remanescente pós-colheita no desempenho agronômico da cultura da cana-de-açúcar, no seu processo de decomposição, e nos níveis dos nutrientes nas folhas. $\mathrm{O}$ experimento foi instalado na Usina Jalles Machado, em Goianésia-GO, utilizando a cultivar IAC SP 91-1099 em área de produção comercial de cana-de-açúcar. Utilizou-se o delineamento de blocos ao acaso, com quatro blocos e cinco tratamentos $(0 \%, 25 \%, 50 \%$, $75 \%$, e $100 \%$ de palhiço residual). A avaliação da decomposição de resíduos e liberação de nutrientes do palhiço para o solo foi feita apenas nos tratamento dois e cinco. Os resultados que apresentaram distribuição normal tiveram médias comparadas pelo teste de Tukey (5\%), e os que não apresentaram distribuição normal foram submetidas ao teste de Kruskal-Wallis com comparações múltiplas. O palhiço apresentou grande potencial de fornecimento de nutrientes para a lavoura no longo prazo. A decomposição dos resíduos foi mais acelerada no tratamento cinco ( $100 \%$ de palhiço residual), na interface solo-palhiço, e não houve diferença entre os tratamentos na interface palhiço-superfície. $O$ tratamento cinco apresentou os menores valores de meia vida. Não houve efeito dos tratamentos nos teores de nutrientes nas folhas. Os tratamentos não apresentaram efeitos significativos nas medidas biométricas, nas análises tecnológicas do caldo, nem na produtividade da cultura.

Palavras chave: 1. Saccharum spp. 2. Palhiço. 3. Cana crua. 4. Decomposição. 5. Ciclagem de nutrientes. 


\begin{abstract}
The sugarcane mechanical harvesting without burning generates great accumulation of straw in the field. The objective of this study was to evaluate the effects of different amounts of post-harvest remaining residues in the agronomic performance of the sugarcane, in its decomposition process, and in the levels of nutrients in the leaves. The experiment was installed at Usina Jalles Machado, in Goianésia-GO, using the IAC SP 91-1099 cultivar in an area of sugarcane commercial production. The randomized blocks experimental design was used, with four blocks and five treatments $(0 \%, 25 \%, 50 \%, 75 \%$, and $100 \%$ of remaining straw). The assessment of the decomposition of the residues a nutrient release was made only in the treatments two and five. The results that were normally distributed had their averages compared by the Tukey test (5\%), and the results that were not normally distributed were compared by the Kruskal-Wallis test with multiple comparisons. The straw showed great potential of nutrient supply for the crop in the long run. The straw decomposition was faster in the treatment number five (100\% of remaining straw), in the soil-straw interface, and no differences were observed between the treatments in the straw-surface interface. The treatment number five presented the lower values for half-life and. There were no effects of the treatments in the levels of macro and micronutrients in the leaves. No significant effects were presented by the treatments regarding the biometric measures of the crop, its juice technological analysis, and its productivity.
\end{abstract}

Key words: 1. Saccharum spp. 2. Straw. 3. Green sugarcane. 4. Decomposition. 5. Nutrient cycling. 


\section{SUMÁRIO}

1. INTRODUÇÃ

2. Objetivos

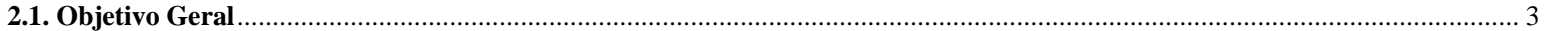

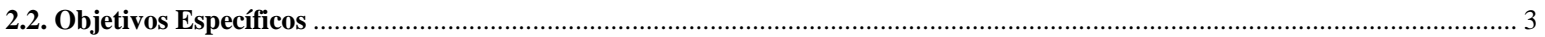

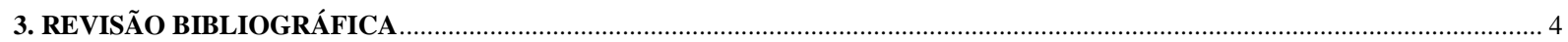

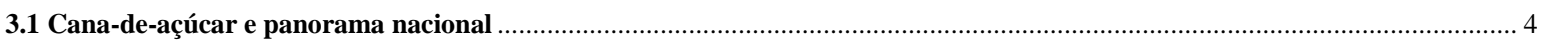

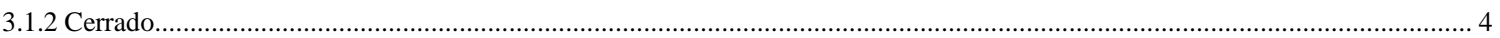

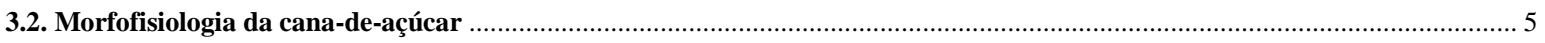

3.3 Solo

3.4 Nutrição

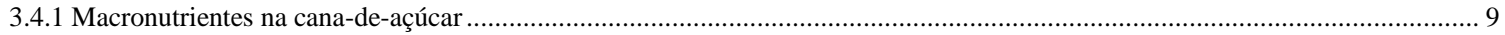

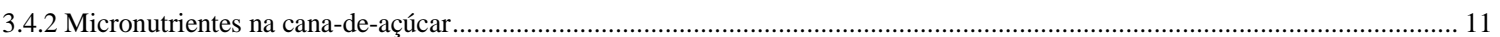

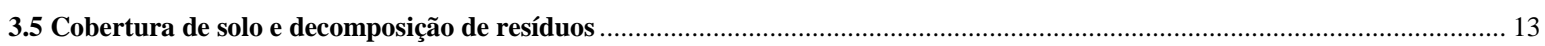

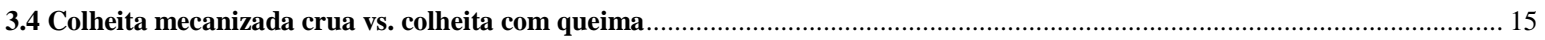

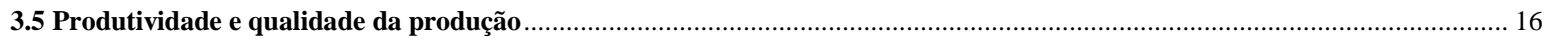

3.6 Cogeração em usinas de cana-de-açúcar e produção de etanol celulósico ……..................................................................... 16

4. MATERIAL E MÉTODOS

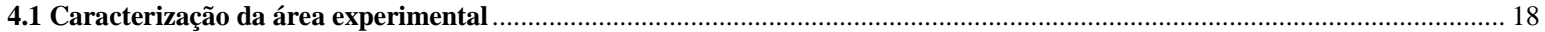

4.2 Instalação do experimento

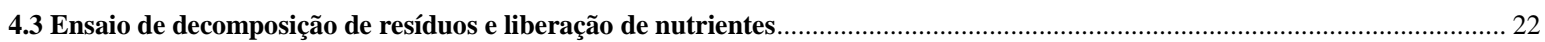

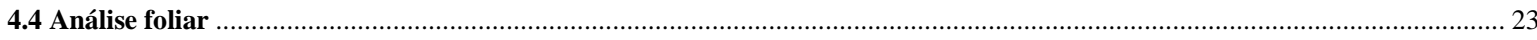

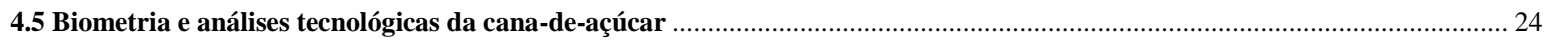

4.6 Produtividade

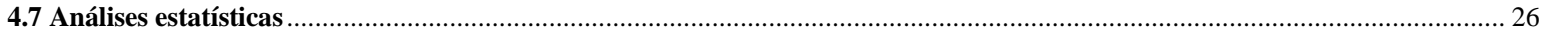

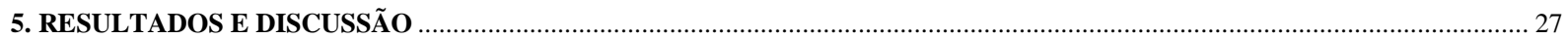

5.1. Ensaio de decomposição e aporte de nutrientes dos resíduos para o solo ……................................................................ 27

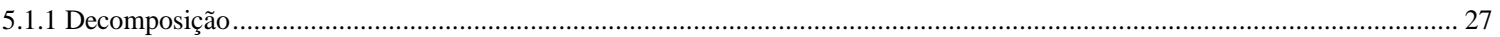

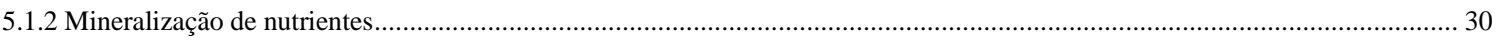

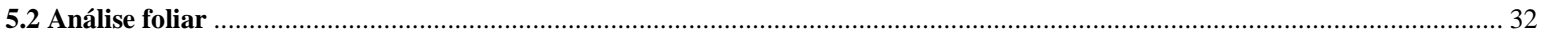

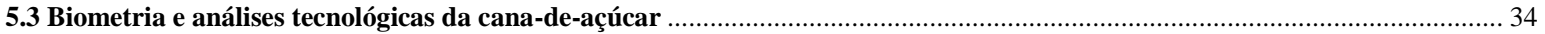

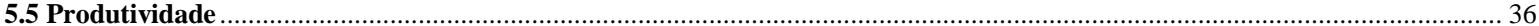

5. CONCLUSÕES

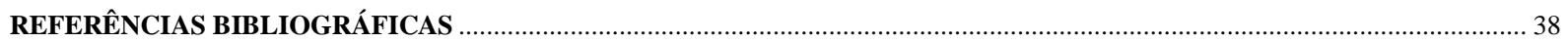




\section{INTRODUÇÃO}

A demanda por fontes renováveis de energia cresce em ritmo acelerado, gerando empregos e novas oportunidades de crescimento econômico. No mesmo ritmo cresce a demanda por processos produtivos mais sustentáveis.

A cadeia produtiva da cana-de-açúcar (Saccharum spp.) se destaca nesse cenário com a produção de etanol, combustível alternativo às fontes fósseis, com alta rentabilidade. Soma-se a isso os recentes avanços em direção à eliminação da colheita pós queima. Tal prática, apesar de apresentar alguns efeitos benéficos (como o controle de pragas, por exemplo, a cigarrinha), é prejudicial ao ar e ao solo, e acarreta perdas à produtividade da cultura (ANDRADE et al., 2011).

O aporte de palhada no sistema garante maior sustentabilidade à cultura, diminuindo as perdas físicas e químicas do solo por erosão (ANDRADE et al., 2011; SOUZA et al., 2012), e garantindo ambiente favorável à atividade microbiana. Ao mesmo tempo, a colheita mecanizada da cana crua faz surgir um panorama no campo antes inexistente: grandes quantidades de resíduos vegetais deixados no campo colheita após colheita.

É importante pontuar a diferença nas nomenclaturas utilizadas para os resíduos, como exposto por Ripoli e Ripoli (2004), em que: palha é a folha seca, ainda anexa ao colmo, ou caída ao chão, com o canavial ainda em pé; palhada é o resíduo da colheita formada por folhas e ponteiros com baixo teor de água (menos de 15\%); o palhiço, por sua vez, engloba a palha, a palhada, e os colmos e frações de colmos remanescentes da colheita, bem como resíduos de plantas daninhas e partículas de solo que se agregam a esses componentes.

O palhiço apresenta períodos de decomposição e reciclagem de nutrientes muito longos, gerando uma cobertura persistente e em alta quantidade (COELHO, 2012), afetando a produção de diversas maneiras, positivas ou negativas (ANDRADE et al., 2011).

De acordo com Macedo et al. (2003), o sistema mecanizado de colheita da cana crua, frente ao sistema com queima, garante melhorias na estrutura e fertilidade do solo e, devido provavelmente às melhorias na estrutura do solo e na mineralização de nutrientes da biomassa, também pode gerar melhores resultados de produção, como peso e diâmetro de colmos, produtividade de colmos e de açúcar. Por outro lado, ainda segundo os autores, uma espessa camada de resíduos pode gerar dificuldades no controle seletivo de plantas daninhas e maior incidência de pragas que se abrigam sob a palha, assim como pode interferir na rebrota da soqueira. Sousa et al. (2012) também encontraram efeitos benéficos do palhiço, mas dessa vez frente à remoção do mesmo. Os autores identificaram significativa redução na quantidade 
de matéria orgânica perdida em sedimentos erodidos quando mantidas quantidades de 10 e 7,5 t.ha ${ }^{-1}$ de palhiço frente à remoção de palhiço acima de $50 \%$ (5 t.ha ${ }^{-1}$ ou menos). A remoção de palhiço a partir da quantidade indicada (50\%) acarretou enriquecimento nos teores de matéria orgânica nos sedimentos erodidos.

O palhiço pode também ser utilizado na cogeração energética pela queima (assim como é feito atualmente com o bagaço), ou ainda na produção de etanol celulósico. A produção de etanol celulósico ainda é incipiente no Brasil, mas a pesquisa e desenvolvimento avançam a passos largos, com vultosos investimentos feitos no setor a partir de 2013, visando o grande potencial de aumento na eficiência da cadeia sucroalcooleira pelo uso da biomassa tanto para produção de etanol como para a cogeração térmica (ÚNICA, 2013). Em contraponto, a manutenção do palhiço na lavoura pode diminuir os custos de produção no longo prazo, devido à mineralização de nutrientes e aporte de matéria orgânica, aumentando a fertilidade do solo.

Visando maior retorno em curto prazo, pode-se ocorrer a remoção de todo o palhiço residual da colheita mecanizada do campo para a produção de etanol ou para a cogeração nas usinas, diminuindo os efeitos do palhiço sobre o solo. Esse cenário pode acarretar a eliminação de grande parte dos efeitos benéficos ambientais e agronômicos provindos da colheita mecanizada e do acúmulo de resíduos orgânicos nas lavouras.

Dessa forma, é imprescindível o entendimento dos efeitos da remoção de níveis do palhiço residual no sistema de produção da cana-de-açúcar. O conhecimento dos impactos da remoção do palhiço na cultura, nos níveis dos diversos nutrientes do solo, assim como na decomposição desse resíduo, se mostra de grande importância para a definição do melhor manejo a ser adotado, visando menores custos de produção e maior rentabilidade e sustentabilidade (tanto ambiental quanto econômica) das usinas. 


\section{Objetivos}

\subsection{Objetivo Geral}

Avaliar os efeitos da remoção de diferentes quantidades de palhiço remanescente na sua decomposição e ciclagem de nutrientes, bem como no estado nutricional e desempenho agronômico da cultura da cana-de-açúcar.

\subsection{Objetivos Específicos}

Determinar os efeitos de dois níveis (25 e 100\%) de palhiço remanescente da colheita e da localização do palhiço (interface palhiço/solo ou interface palhiço/superfície) na sua taxa decomposição e no aporte de material orgânico e nutrientes para o solo;

Determinar os efeitos de cinco níveis $(0,25,50,75$, ou 100\%) de palhiço remanescente da colheita no estado nutricional da cana-de-açúcar;

Determinar os efeitos de cinco níveis $(0,25,50,75$, ou 100\%) de palhiço remanescente da colheita nas características biométricas (altura de colmo, diâmetro de colmo, massa de colmo) e nas qualidades tecnológicas (teor de fibra, grau Brix, pureza do caldo, e açúcares totais recuperáveis) da cana-de-açúcar, e na produtividade da cultura. 


\section{REVISÃO BIBLIOGRÁFICA}

\subsection{Cana-de-açúcar e panorama nacional}

O Brasil atualmente é líder em pesquisa e desenvolvimento, tanto da cultura quanto dos processos produtivos e de processamento. O país é também líder em produção total (PICOLI, 2009), apresentando alto grau de tecnificação das lavouras tanto em processos produtivos quanto em biotecnologia.

As cadeias produtivas do açúcar e do etanol são de grande importância para a economia brasileira. A alta demanda do mercado interno por etanol é puxada pela grande quantidade de veículos bicombustíveis vendidos no país, sendo que em 2010 86\% dos veículos leves novos vendidos foram do tipo bicombustível (ANFAVEA, 2010). A indústria açucareira é atualmente a maior produtora mundial, atendendo ao mercado interno e às altas demandas vindas da Europa e China.

A cana-de-açúcar apresenta grande potencial de expansão. O país apresenta, além dos atuais nove milhões de hectares ocupados por canaviais, mais 65 milhões de hectares propícios ao plantio de cana-de-açúcar, dos quais aproximadamente 14 milhões são de alta aptidão (ZAE CANA, 2009).

Quanto à convivência com outras culturas e produção de alimentos, o Brasil se destaca pela não competição entre canaviais e áreas produtoras de alimentos. Isso coloca o país em vantagem frente a fortes competidores do setor, como EUA e União Europeia (ZAE CANA, 2009).

Com áreas disponíveis e produtividade crescente, além do mercado de combustíveis favorecendo as fontes não fósseis, o Brasil se encontra em uma posição favorável à expansão de sua liderança na produção de etanol e açúcar.

\subsubsection{Cerrado}

O Cerrado apresenta aproximadamente 204 milhões de hectares, sendo o segundo maior bioma brasileiro, depois da Amazônia. O bioma se estende pelas unidades federativas do Pará, Maranhão, Ceará, Bahia, Tocantins, Rondônia, Goiás, Minas Gerais, Mato Grosso, Mato Grosso do Sul, e Distrito Federal, cobrindo grande parte do território nacional (EITEN, 1993; EMBRAPA, 2007).

Áreas de Cerrado apresentam enorme potencial agrícola, desde que feitos os investimentos necessários em melhorias do solo. Com pesquisa constante em melhores manejos para os solos e variedades com melhor adaptação é possível conseguir consideráveis 
saltos de produtividade no Cerrado, aumentando a produção agrícola sem ameaçar áreas de preservação (GOEDERT, 1985; EITEN, 1993).

Os solos predominantes no Cerrado são Latossolos Vermelhos e Vermelho-Amarelos (REATTO et al., 1998). São solos profundos porosos, permeáveis, e bem drenados, o que favorece a mecanização e a agricultura em larga escala, porém favorece também a lixiviação, tornando-os pobres em nutrientes e ricos em ferro e alumínio. Estes solos apresentam baixo teor de matéria orgânica, cerca de 3-5\% (CORREIA et al., 2004).

Os Latossolos podem apresentar $\mathrm{pH}$ variando de menos que 4 a pouco mais que 5 , e ainda podem apresentar altas concentrações de alumínio, o que os torna tóxicos a diversas culturas (COUTINHO, 2000). Dessa forma, demandam boas doses de adubação corretiva para se obter rendimentos adequados com as principais culturas comerciais (SPERA et al., 2006).

O Cerrado apresenta clima estacional de savana, com inverno seco e verão chuvoso (KÖPPEN; GEIGER, 1928). Apresenta ainda precipitação média anual em torno de $1.500 \mathrm{~mm}$ e temperaturas amenas, com médias variando de $22^{\circ} \mathrm{C}$ a $27^{\circ} \mathrm{C}$ (KLINK; MACHADO, 2005). Junto a esses fatores, os solos de Cerrado apresentam baixa retenção hídrica, o que torna a disponibilidade de água um dos principais fatores limitantes para a produção agrícola no Cerrado.

A cultura da cana-de-açúcar tem avançado bem sobre o Cerrado, principalmente com o preparo e adubação corretas, assim como com a colheita mecanizada da cana crua, que gera grande aporte de palhiço para o solo, o que ajuda a contornar ou diminuir a limitação da retenção hídrica. O acúmulo de palhiço proveniente do uso de técnicas conservacionistas protege o solo da lixiviação na época chuvosa, bem como da perda excessiva de umidade no período seco. Dessa forma, tais técnicas tornam-se aliadas de grande importância para a agricultura em regiões de Cerrado.

A presença da indústria sucroalcooleira nas regiões de Cerrado diversifica a economia dessas regiões, trazendo mais estabilidade com a menor dependência de outras fontes de renda.

\subsection{Morfofisiologia da cana-de-açúcar}

A cana-de-açúcar (Saccharum spp.) é uma planta da família Poaceae, gênero Saccharum (CRONQUIST, 1981). A cultivares conhecidas hoje são, em geral, híbridos das diversas espécies conhecidas, obtidos por cruzamentos buscando mesclar características 
favoráveis das diversas espécies à riqueza em açúcar de variedades nobres de Saccharum officinarum.

Há controvérsia quanto ao local exato do centro de origem da cana-de-açúcar, apesar de existir consenso entre diversos autores que esse centro está aproximadamente no sudeste asiático. A maior diversidade de espécies se encontra na China, Índia, e Nova Guiné (CLAYTON; DANIELS, 1975). Hoje os híbridos de cana estão espalhados por mais de 100 países.

É uma poacea tropical semi-perene, apresenta uma longa haste (colmo) na qual a sacarose é acumulada, que cresce a partir de rizomas. Seu plantio é feito a partir de rebolos (colmos), gerando perfilhos, que funcionam como plantas independentes entre si, com órgãos próprios como raízes, folhas, etc. Entretanto, plantas da mesma touceira podem eventualmente partilhar nutrientes entre si. O perfilhamento da cultura é afetado por diversos fatores, passíveis ou não de manejo, como luz, temperatura, umidade do solo, disponibilidade de nutrientes, entre outros. Também influenciam no perfilhamento as características genéticas da variedade (SCARPARI; BEAUCLAIR, 2010).

A planta é formada basicamente por sistema radicular, colmo, folha, e inflorescência. Além da função de fornecimento de água e nutrientes, as raízes têm a função de sustentação da planta. Martin (1961) observou que as raízes se afinavam em direção ao seu extremo de crescimento, e que em suas pontas há uma capa protetora com função de proteger as células em atividade de divisão. Não há um padrão quanto à arquitetura das raízes, havendo diferenças na arquitetura das raízes de diferentes variedades (SCARPARI; BEAUCLAIR, 2010). A arquitetura da raiz é afetada também pela idade da planta, que nos primeiros dois anos apresenta maior atividade na porção superficial do solo, e é mais afetada pela adubação e calagem, enquanto nos anos mais avançados de produção a cana é mais afetada pelas características físico-químicas da porção subsuperficial do solo (LANDELL et al. 2003).

Os colmos da cana-de-açúcar podem ser definidos como a porção da planta acima do solo que sustenta as folhas e a inflorescência. São de formato cilíndrico, e são constituídos por nós e entrenós. É no colmo onde ocorre a acumulação do açúcar na planta. O alongamento dos entrenós é o que propicia o crescimento dos colmos. Cada nó apresenta uma gema, com disposições alternadas ao longo do colmo. Os colmos podem apresentar diversos formatos e tamanhos, afetados tanto pelo genótipo das variedades, como pelo manejo de água, nutrientes, e preparo do solo. 
A cana-de-açúcar possui folhas longas, com serras nos bordos e nervura principal e formato de canaleta, e medindo 0,5 a $1,5 \mathrm{~m}$ de comprimento e 2,5 a $10 \mathrm{~cm}$ de largura, dependendo da variedade (SCARPARI; BEAUCLAIR, 2010). Suas principais funções são as trocas de gases e água, respiração, e fotossíntese. As folhas são inseridas no colmo por estruturas conhecidas como bainhas, de onde se estende a lâmina foliar. As folhas podem ser classificadas pelo sistema de Kujiper, segundo o qual são classificadas por números negativos, zero, e positivos. A primeira folha com a aurícula visível é a folha +1 , sendo as folhas acima dela a folha zero e as folhas negativas, e as folhas abaixo as folhas positivas (DILLEWIJN, 1952).

A inflorescência é o conjunto de flores da cana-de-açúcar, e tem o formato de panícula ou flecha. O florescimento ocorre em condições restritas de luz e temperatura e umidade, e é um fenômeno altamente indesejável na produção da cultura, exceto quando para fins de cruzamento. O florescimento consome grandes quantidades de açúcar do colmo, e acarreta um fenômeno conhecido como isoporização, que em áreas de produção comercial gera grandes prejuízos. Visando a redução do florescimento é recomendado o uso de variedades com baixo ou nenhum potencial florífero, especialmente em áreas com condições ambientais favoráveis à floração. Quando houver impossibilidade do manejo varietal, o uso de produtos inibidores de florescimento deve ser usado (ARALDI et al., 2010).

As fases de desenvolvimento da cultura são divididas em brotação e emergência, perfilhamento, crescimento dos colmos, e maturação dos colmos, e estão descritas a seguir (MARIN et al., 2008).

Cerca de 30 dias após o plantio se inicia a brotação. O broto rompe a gema e se desenvolve em direção à superfície, formando o colmo primário. Concomitantemente surgem as raízes do rebolo e o aparecimento das primeiras folhas. Os principais fatores para o sucesso dessa fase é a qualidade dos rebolos, manejo e época do plantio, e o clima. Em seguida se inicia o perfilhamento, que é a formação da touceira. É a emissão de brotos, em 20 a 30 dias após a emergência do colmo primário, que vão em direção à superfície. Forma-se também o sistema radicular da touceira, que é conjunto dos sistemas radiculares dos diversos perfilhos. O auge do perfilhamento se dá no momento em que as folhas da planta cobrem o máximo de área, o que coincide com o máximo de perfilhos (SCARPARI; BEAUCLAIR, 2010).

Após o perfilhamento máximo há o crescimento dos colmos, quando começa também o acúmulo de açúcar em suas bases. Durante essa fase as folhas velhas (as primeiras emitidas) começam a amarelar e secar. Essa fase é estimulada principalmente por luz umidade e calor. 
Posteriormente, o sistema radicular se desenvolve com mais vigor, tanto nas laterais quanto em profundidade, e o mesmo se concentra na camada até $40 \mathrm{~cm}$ de profundidade, onde ocorre a maior parte da absorção de água e nutrientes (MARTIN, 1961).

A maturação dos colmos se inicia com o intenso crescimento dos colmos finais desenvolvidos após o perfilhamento das touceiras, e o açúcar no início, como mencionado acima, se concentra na base da planta. Quando a altura do dossel ultrapassa os dois metros, as folhas da porção mediana da planta começam a secar, indicando o início do depósito de açúcar na região. Quando a atividade de crescimento começa a cessar, inicia-se a fase final de maturação e intenso acúmulo de açúcar, com aumento na concentração no terço superior da planta. A colheita é indicada quando a concentração de açúcar no terço superior da planta se aproxima do valor encontrado no terço inferior da planta (SCARPARI; BEAUCLAIR, 2010).

Os ciclos da cana-de-açúcar podem ser de aproximadamente 14 a 22 meses, 12 meses, ou 16 meses, e são caracterizados como cana de ano e meio, cana de ano, ou cana de inverno, respectivamente (CANTARELLA, 2010).

O plantio da cana-de-açúcar é restrito aos paralelos $35^{\circ}$ Norte e $35^{\circ} \mathrm{Sul}$, apresentando melhor desenvolvimento entre temperaturas de $30^{\circ} \mathrm{C}$ e $34^{\circ} \mathrm{C}$, com água disponível e estação seca suave (CANTARELLA, 2010). A cana-de-açúcar é uma planta do tipo C4, apresenta alta eficiência fotossintética e ótimo crescimento sob altas temperaturas, encontrando vastas áreas propícias ao seu cultivo no Brasil. A produtividade de colmos no primeiro ano (maior do que nos anos seguintes) varia de 120 a $200 \mathrm{t} \mathrm{ha}^{-1}$, e nos anos seguintes gira em torno de $70 \mathrm{t} \mathrm{ha}^{-1}$, dependendo do manejo adotado (CANTARELLA, 2010). Dentre as culturas comercias, apresenta alto potencial para produção de biomassa. A produtividade média brasileira na safra de 2014/2015 foi aproximadamente $74 \mathrm{t} \mathrm{ha}^{-1}$ (CONAB, 2014).

\subsection{Solo}

A cultura se desenvolve bem em solos profundos, que permitam um bom preparo do solo e desenvolvimento do sistema radicular. Solos de textura média (tendendo para textura argilosa) e com relevo plano são preferíveis devido à facilidade de mecanização, menor susceptibilidade à erosão, e maior disponibilidade de água (PRADO et al., 2010).

O correto preparo do solo para o plantio ou reforma do canavial, com subsolagem, aração, ou gradagem, com adubação e calagem adequadas, são essenciais para que a cana-deaçúcar atinja produtividades elevadas. Níveis de bases devem ser de médios a altos, ao passo que deve haver baixa presença de alumínio. À medida que a lavoura avança no tempo, a 
planta passa a exigir mais da camada subsuperficial do solo, que é beneficiada por um preparo bem executado (PRADO et al., 2010).

\subsection{Nutrição}

Os níveis adequados de macro e micronutrientes, bem como a reposição ao longo dos cortes da quantidade dos nutrientes consumidos pela lavoura são essenciais para o sucesso na produção da cana-de-açúcar.

\subsubsection{Macronutrientes na cana-de-açúcar}

Os valores de macronutrientes extraídos por 100 toneladas de colmos produzidos e os valores adequados para os teores de macronutrientes nas folhas da cana-de-açúcar em condições do Brasil estão apresentados nas Tabelas 1 e 2, respectivamente.

Tabela 1. Extração de macronutrientes para produção de 100 toneladas de colmos (ORLANDO FILHO, 1993).

\begin{tabular}{cccccc}
\hline $\mathbf{N}$ & $\mathbf{P}$ & $\mathbf{K}$ & $\mathbf{C a}$ & $\mathbf{M g}$ & $\mathbf{S}$ \\
& - & & & \\
& & & & & \\
\hline 143 & 19 & 174 & 87 & 49 & 44 \\
\hline
\end{tabular}

Tabela 2. Faixas de teores adequados de micronutrientes nas folhas da cana-de-açúcar em condições do Brasil (RAIJ; CANTARELLA, 1997).

\begin{tabular}{|c|c|c|c|c|c|}
\hline $\mathbf{N}$ & $\mathbf{P}$ & $\mathbf{K}$ & $\mathbf{C a}$ & Mg & $\mathbf{S}$ \\
\hline $18-25$ & $1,5-3$ & $10-16$ & $2-8$ & $1-3$ & $1,5-3$ \\
\hline
\end{tabular}

Em um estudo com plantio de cana em solução nutritiva, do Vale et al. (2011) observaram que nitrogênio $(\mathrm{N})$ e fósforo $(\mathrm{P})$ foram os nutrientes que mais limitaram o crescimento da parte aérea da planta, ao passo que $\mathrm{N}$ e cálcio $(\mathrm{Ca})$ foram os que mais limitaram o crescimento das raízes.

Vitti et al. (2010), citando Malavolta et al. (1997), dissertaram sobre a importância do $\mathrm{N}$ na cultura da cana-de-açúcar, sendo esse um dos principais nutrientes no desenvolvimento da cultura, e o segundo mais absorvido, atrás apenas do K. Os autores citaram ainda que o suprimento de $\mathrm{N}$ se dá principalmente por fluxo de massa, e que o nutriente, apesar de compor 
apenas $1 \%$ da matéria seca da planta, tem atuação essencial no seu desenvolvimento, sendo constituinte de proteínas, ácidos nucléicos, e da clorofila, participando ainda de vários processos bioquímicos e enzimáticos.

Deficiência de N na cana-de-açúcar pode acarretar clorose nas folhas mais velhas, afetando o perfilhamento e a eficiência fotossintética, e consequentemente afetando o desenvolvimento geral da cultura (VITTI et al., 2010).

Devido à sua função nas estruturas celulares e atuação nos processos de formação e transferência de energia, $\mathrm{P}$ é um dos nutrientes mais limitantes à cultura da cana-de-açúcar. Sua deficiência afeta a produção não só quantitativamente, mas também qualitativamente. A primordial função exercida pelo $\mathrm{P}$ na cana-de-açúcar é a formação do açúcar, componente principal para a qualidade da produção. Atua ainda nos processos de divisão e alongamento das células, bem como na transferência de informações genéticas (ROSSETTO et al., 2010).

Deficiência de $\mathrm{P}$ causa raquitismo nas plantas, afetando a qualidade e desenvolvimento da lavoura. Outros sintomas são baixo perfilhamento e coloração arroxeada nas folhas mais velhas, bem como estreitamento e encurtamento das mesmas (NOVAIS et al., 2007).

Como mencionado anteriormente, $\mathrm{K}$ é o nutriente mais absorvido pela cana-de-açúcar. Dentre as diversas funções do nutriente nas plantas, destaca-se sua participação em muitos processos enzimáticos, os quais participam da fotossíntese e respiração (ERNANI et al., 2007).

Rossetto et al. (2010) mencionaram que a maior parte do K absorvido pela planta é acumulado nos colmos, enquanto cerca de $45 \%$ do nutriente é acumulado nas folhas, que futuramente formarão a palhada na lavoura. Dessa forma, em sistemas de colheita mecanizada sem queima, há uma grande reciclagem de K, e mesmo o nutriente acumulado nos colmos, retorna, em parte, para a lavoura na forma de resíduos da usina (torta de filtro, cinzas, e vinhaça, por exemplo).

Ernani et al. (2007) citaram como principais sintomas da deficiência de K a redução do tamanho dos internódios, da dominância apical, e do crescimento geral das plantas. Também são sintomas de tal deficiência a clorose na borda das folhas (começando pelas folhas mais velhas), com posterior necrose das mesmas.

Vitti et al. (2010) observaram que em cana-de-açúcar o enxofre é menos absorvido que os demais macro nutrientes, e sua concentração nas plantas varia muito quanto à fase de desenvolvimento da planta analisada. Os autores citaram ainda que o $\mathrm{S}$ geralmente é pouco retido nas camadas superficiais do solo $(0-20 \mathrm{~cm})$, e que o diagnóstico mais eficiente é obtido 
com a análise de camadas mais profundas $(0-40 \mathrm{~cm}$, por exemplo). A maior parte do $\mathrm{S}$ no solo está presente na fração orgânica, daí a importância da matéria orgânica do solo (MOS) para a presença desse nutriente nas lavouras. Deficiência de S, ainda segundo Vitti et al. (2010), acarreta clorose em folhas nova e raquitismo, afetando significativamente a produtividade da lavoura.

$\mathrm{Ca}$ e $\mathrm{Mg}$ são, geralmente, incorporados na lavoura como corretivos, e não como fertilizante. A calagem do solo apresenta respostas significativas na produtividade da cana-deaçúcar, mesmo com uma baixa elevação na saturação por bases do solo para $25 \%$, o que mostra a tolerância da cana à acidez dos solos (QUAGGIO, 2000). A aplicação de gesso agrícola também afeta a produção, melhorando a distribuição de $\mathrm{Ca}$ e $\mathrm{Mg}$ no perfil do solo, permitindo a penetração dos nutrientes nas camadas mais profundas (QUAGGIO; RAIJ, 2010).

Como nutriente, o Ca participa da formação da parede celular, sendo importante nas interações feitas pelas membranas intercelulares. $\mathrm{O} \mathrm{Mg}$, por sua vez, faz parte da composição estrutural da clorofila e tem o papel de ativador de algumas enzimas (SOUSA et al., 2007).

\subsubsection{Micronutrientes na cana-de-açúcar}

Os valores de micronutrientes extraídos por 100 toneladas de colmos produzidos e os valores adequados para os teores de micronutrientes nas folhas da cana-de-açúcar em condições do Brasil estão apresentados nas Tabelas 3 e 4, respectivamente.

Tabela 3. Extração de micronutrientes para produção de 100 toneladas de colmos (ORLANDO FILHO, 1993)

\begin{tabular}{ccccc}
\hline B & Cu & Fe & Mn & Zn \\
& $-1-100$ & \\
\hline 235 & 339 & 7318 & 2470 & 592 \\
\hline
\end{tabular}

Tabela 4. Faixas de teores adequados de micronutrientes nas folhas da cana-de-açúcar em condições do Brasil (RAIJ; CANTARELLA, 1997).

\begin{tabular}{|c|c|c|c|c|c|}
\hline B & $\mathbf{C u}$ & $\mathbf{F e}$ & Mn & Mo & $\mathrm{Zn}$ \\
\hline $10-30$ & $6-15$ & $40-250$ & $25-250$ & $0,005-0,2$ & $10-50$ \\
\hline
\end{tabular}


Buscando mais eficiência na produção, variedades de cana-de-açúcar mais produtivas estão sendo desenvolvidas. A maior capacidade de desenvolvimento das plantas muitas vezes consome mais nutrientes do solo. Por vezes há grande preocupação com NPK e macro nutrientes secundários, e negligenciam-se os micronutrientes. Em ambientes cada vez mais eficientes, com consumo crescente de insumos, baixos teores de micro nutrientes nos solos podem acarretar perdas em produtividade (MELLIS et al., 2010).

Dentre os micronutrientes, o zinco $(\mathrm{Zn})$ é o que mais afeta a produção da cana-deaçúcar. O nutriente é essencial à produção do triptofano, precursor do hormônio do crescimento (AIA - ácido indolilacético), de forma que plantas deficientes em $\mathrm{Zn}$ sofrem de raquitismo, e apresentam como sintoma clorose nas folhas em forma de estrias, podendo acarretar à necrose das folhas (TAIZ; ZEIGER, 2004). Muito importante também é o cobre $(\mathrm{Cu})$, que atua na ativação de diversas enzimas importantes para os processos fotossintéticos. Plantas deficientes em cobre apresentam problemas na fotossíntese, o que afeta seu desenvolvimento. Sintomas da deficiência são clorose e murcha nas folhas novas, podem também ocorrer envergamento dessas. Colmos e meristemas perdem turgidez e murcham, podendo ocorrer o caimento do topo da planta (MELLIS et al., 2010).

Outro elemento essencial à fotossíntese é o cloro $(\mathrm{Cl})$, o qual geralmente é fornecido às plantas como parte do $\mathrm{KCl}$ usado como fonte de potássio nas lavouras (ANDERSON; BOWEN, 1992). Ferro (Fe) também é um elemento cuja deficiência é rara, especialmente em Latossolos no Cerrado. As principais funções do nutriente são a formação estrutural de diversas enzimas, transporte eletrônico, bem como tem papel fundamental na síntese da clorofila (ORLANDO FILHO et al., 2001).

Há controvérsia quanto ao papel do boro (B) nos processos fisiológicos da cana-deaçúcar, sendo que Orlando Filho et al. (2001) defendem que o elemento participa do transporte de carboidratos das folhas para os demais órgãos da planta. Sua deficiência compromete o desenvolvimento apical, acarretando folhas com deformações e presença de necrose. Pode também causar toxicidade quando concentrado em excesso na planta, causando clorose nas margens das folhas novas.

Manganês (Mn) participa ativamente em diversas reações do ciclo de Krebs, tendo importante papel na respiração vegetal. Sua deficiência causa sintomas semelhantes aos da deficiência de $\mathrm{Fe}$, nas folhas jovens, que podem chegar à necrose longitudinal nas folhas e fendilhamento (ORLANDO FILHO et al., 2001). 
O molibdênio (Mo), por sua vez, tem efeito sobre as reações de redutase do nitrato e nitrogenase, o que o torna imprescindível para a fixação biológica do $\mathrm{N}$ pela cana-de-açúcar. Plantas deficientes em Mo apresentas estrias cloróticas longitudinais, podendo acarretar a secagem prematura das folhas em casos avançados de deficiência. Os colmos também sofrem, tornando-se mais curtos e finos (ORLANDO FILHO et al., 2001).

Becari (2010) conduziu experimento visando o entendimento dos efeitos de aplicação de micronutrientes em cultivo de cana-de-açúcar. $\mathrm{O}$ autor observou que a aplicação de zinco $(\mathrm{Zn})$, manganês $(\mathrm{Mn})$, cobre $(\mathrm{Cu})$, boro $(\mathrm{B})$, e molibdênio $(\mathrm{Mo})$ em solos de baixa fertilidade natural teve efeitos positivos na produtividade agrícola e industrial da cultura, ao passo que a aplicação dos mesmos nutrientes apresentou efeitos nulos na qualidade industrial (açúcares totais recuperáveis, pureza do caldo, etc.). Nesse experimento, Zn foi o nutriente que mais impactou a produtividade da lavoura.

\subsection{Cobertura de solo e decomposição de resíduos}

A fase sólida dos solos é constituída pelas frações mineral e orgânica. A fração orgânica corresponde à matéria orgânica do solo, que é composta por $58 \%$ de carbono orgânico. O carbono orgânico do solo sofre alta influência do aporte de material vegetal (por exemplo, o palhiço) e da decomposição deste (SILVA; MENDONÇA, 2007).

De acordo com Ripoli e Ripoli (2004), os resíduos são diferenciados da seguinte forma: palha é a folha seca, ainda anexa ao colmo, ou caída ao chão, com o canavial ainda em pé; palhada é o resíduo da colheita formada por folhas e ponteiros com baixo teor de água (menos de 15\%); o palhiço, por sua vez, engloba a palha, a palhada, e os colmos e frações de colmos remanescentes da colheita, bem como resíduos de plantas daninhas e partículas de solo que se agregam a esses componentes.

O acúmulo de material vegetal e a mineralização do mesmo traz melhorias físicas, químicas, e biológicas ao solo, garantindo um ambiente desejável para o desenvolvimento das plantas (COELHO, 2012).

A mineralização dos resíduos vegetais acarreta maior ciclagem de nutrientes. O manejo com revolvimento mínimo do solo associado a grandes aportes de biomassa favorecem a proteção do solo contra perdas nutricionais e de sedimentos, mas diminuem a ciclagem de nutrientes provenientes dos resíduos. Por outro lado, manejos com incorporação dos resíduos favorecem a ciclagem de nutrientes e mineralização da matéria orgânica do solo (CARVALHO, 2005). 
O processo de decomposição de resíduos vegetais é um processo constante nas superfícies de solos onde há cobertura vegetal. A decomposição é afetada por diversos fatores, como os componentes estruturais dos resíduos, celulose, hemicelulose, e lignina. Carvalho (2005) identificou relações diretas entre o teor de lignina em resíduos de plantas de cobertura e sua decomposição, de forma que quanto maiores os níveis de lignina no material vegetal menores foram suas taxas de decomposição, favorecendo a manutenção do palhiço sobre o solo.

Resíduos vegetais provindos de gramíneas são mais estáveis, pois apresentam alta relação $\mathrm{C} / \mathrm{N}$ (maior que 25), contribuindo para melhor estruturação do solo, e para proteção do mesmo frente à erosão e à solarização. Resíduos com baixa relação C/N (menor que 20) apresentam maiores taxas de decomposição, e consequentemente, a mineralização é mais acelerada, favorecendo maior ciclagem de nutrientes, mesmo sem a sua incorporação (COSTA, 1991). Relação C/N apresenta considerável relevância para o manejo de plantas de cobertura mantidas na superfície ou incorporadas ao solo (CARVALHO et al., 2011).

A relação $\mathrm{C} / \mathrm{N}$ do palhiço da cana-de-açúcar é considerada alta (aproximadamente 100:1), dessa forma é esperada uma decomposição muito lenta, com possível mobilização de nitrogênio pelos microrganismos do solo que agem na decomposição de resíduos (JOHNSON et al., 2007; GRAHAM et al., 2002).

Estudos mostram que, no Brasil, o palhiço geralmente representa de 9 a $20 \%$ do total de colmos produzidos (LANDELL et al., 2013), ou entre 6,75 e 15 toneladas por hectare para a produtividade média brasileira em 2014. Esses valores aliados à taxa de decomposição aproximada de 60\% dos resíduos ao ano (COELHO, 2012) indicam um aporte de até 9 toneladas de material orgânico ao ano por hectare.

As altas quantidades de palhiço remanescente de cada colheita aliadas à sua decomposição lenta podem dar a impressão de que o palhiço não contribuiria com tanta grandeza para a fertilidade do solo e ciclagem de nutriente. Entretanto, estudo recente de longo prazo indica um aporte de aproximadamente $40 \mathrm{~kg}$ de $\mathrm{N}$ por hectare ao ano, com lenta disponibilização do nutriente no início do estudo, e estabilização desse valor após 40 anos de lavoura (aproximadamente 8 renovações de canavial) (TRIVELIN et al., 2013). Esse mesmo estudo indica que $75 \%$ do $\mathrm{K}_{2} \mathrm{O}$ e $50 \%$ do $\mathrm{N}$ são acumulados nos ponteiros, o que mostra a importância da manutenção dos ponteiros da cana-de-açúcar no campo para uma diminuição dos custos de reposição de nutrientes no longo prazo. 
O conhecimento de fatores como a taxa de mineralização de nutrientes e a consequente economia em insumos, bem como os benefícios ambientais da manutenção do palhiço no campo é de grande importância para uma melhor indicação de manejos e tomadas de decisões sobre os resíduos das culturas (COELHO et al., 2010). Apesar do avanço dos estudos sobre o assunto, ainda não há consenso sobre quanto palhiço pode-se remover da lavou sem que haja efeitos maléficos à lavoura em longo prazo (sabe-se que a remoção total do palhiço não é recomendável), e alguns resultados mostram que mais importante é manter os ponteiros no campo, dando-se preferência à remoção (sem indicar uma quantidade adequada) da palhada remanescente (FRANCO et al., 2013; TRIVELIN et al., 2013).

\subsection{Colheita mecanizada crua vs. colheita com queima}

Amaral e Anex (2010) indicaram, como fatores a serem analisados como indicadores ambientais para a cultura, as emissões de gases de efeito estufa (tanto na produção como no processamento), o consumo e a eficiência no uso de fertilizantes e uso do solo, o manejo de doenças e pragas, a conservação da biodiversidade, e a qualidade do ar. Todos esses fatores são fortemente afetados pelo tipo de colheita processada.

Durante muito tempo, uma grande dificuldade para a indústria sucroalcooleira brasileira foi a colheita. Diante da falta de alternativas para a colheita mecanizada, a colheita manual com a queima dos canaviais dominava o país. Tal prática traz diversos problemas à lavoura, ao ambiente, e aos trabalhadores rurais dos canaviais. A colheita com queima gera poluição do ar, acarretando doenças aos trabalhadores e à população rural e urbana das cercanias das propriedades (RIBEIRO; PESQUEIRO, 2010), e é responsável por perdas nutricionais e físicas de solo. O manejo aplicado ao palhiço residual pode gerar maiores ou menores perdas nutricionais e perdas de solo, impactando a sustentabilidade da cultura (IZIDORIO, 2005).

A colheita mecânica garante menores perdas físicas e químicas ao solo, e preserva a microfauna do mesmo. Garbiate et al. (2011) identificaram influência negativa da queima da cana na qualidade física do solo, gerando ainda maiores perdas e maiores danos com o trânsito de máquinas. $\mathrm{O}$ acúmulo de resíduos resultantes da colheita da cana crua não diminuiu o volume das enxurradas nos sulcos, mas acarretou menores perdas de sedimentos e de matéria orgânica.

Apesar de apresentar diversos aspectos positivos, o acúmulo excessivo de resíduos pode trazer dificuldades à lavoura. Há estudos onde foram observados problemas com 
controle de plantas daninhas e com a rebrota da cultura, bem como a população de nematóides (VASCONCELOS, 2002; DINARDO-MIRANDA; FRACASSO, 2013).

\subsection{Produtividade e qualidade da produção}

Paralelamente ao efeito no microambiente do solo, o palhiço também apresenta impactos sobre a produtividade e qualidade da cana-de-açúcar. A produtividade da cultura e a qualidade de caldo são afetados diretamente por fatores ambientais, como temperatura, retenção de água no solo, entre outros (SOUZA et al., 2005).

Campos et al. (2012) identificaram resposta positiva da cultura em termos de produtividade e medidas biométricas com a presença de cobertura do solo por palhiço. Porém, estes mesmos autores, identificaram resposta negativa do Pol (\%) com a cobertura do solo. Os mesmos autores também observaram a maior retenção hídrica no solo coberto com palhiço, o que afetou a composição química do caldo e o desenvolvimento da cultura.

Em estudo comparativo entre manejos do palhiço, Souza et al. (2005) observaram efeito positivo do manejo do palhiço na produtividade de colmos e sacarose. Quando triturado e incorporado ao solo, o palhiço afetou positivamente a produtividade, mas não houve efeito sobre a qualidade do caldo.

$\mathrm{O}$ aumento na produtividade e as melhorias ambientais geradas pela cobertura do solo por palhiço são fatores importantes a serem analisados na tomada de decisão quanto ao manejo deste palhiço.

\subsection{Cogeração em usinas de cana-de-açúcar e produção de etanol celulósico}

A cogeração de energia em usinas de cana-de-açúcar por queima de resíduos tem grande potencial no Brasil. Além de garantir energia, a cogeração garante mais rentabilidade às usinas com o repasse do excedente de energia produzido às companhias distribuidoras. Atualmente os principais meio de cogeração são micro estações termoelétricas situadas nas próprias usinas, abastecidas pelo bagaço da cana (RANGEL et al., 2014).

Com a implantação da colheita mecanizada de cana crua, a atenção das usinas tem se concentrado no palhiço residual. Como citado anteriormente, no Brasil o palhiço equivale a 9 a $20 \%$ do total de colmos produzidos (LANDELL et al., 2013), ou entre 6,75 e 15 toneladas por hectare para a produtividade média brasileira em 2014, quantidade considerável de biomassa para a produção termoelétrica, se somada ao bagaço. 
A indústria sucroalcooleira apresenta grande potencial para geração de energia através de seus resíduos. O potencial de produção de energia por queima de biomassa nas usinas é de aproximadamente $45-58 \%$ do potencial de produção da usina hidroelétrica de Itaipu (MENEGELLO; CASTRO, 2007), potencial que pode crescer o a inclusão do palhiço no material para cogeração.

Dessa forma, o setor sucroalcooleiro pode também contribuir na diversificação e descentralização da matriz energética brasileira, devido ao alto potencial energético das usinas, vindo a cogeração a se tornar um importante segmento de negócios do setor (MENEGELLO; CASTRO, 2007).

Outro uso potencial do palhiço da cana-de-açúcar é a produção de etanol de segunda geração (2G), ou etanol celulósico. A cana se destaca nesse quesito, com grande produção de biomassa, e com uma tonelada de palhiço residual equivalendo a 1,2-2,8 EBP (equivalente barris de petróleo) (RIPOLI, 2010).

A pesquisa caminha a passos largos em direção ao desenvolvimento de processos eficiente de produção de etanol $2 \mathrm{G}$, com as primeiras usinas em operação em 2013. No Brasil a primeira usina com operação comercial iniciou suas atividades em 2014. Pesquisas indicam produção 340 litros de etanol por tonelada de palha (LAU et al., 2007).

Visando essa nova fonte de etanol, programas de melhoramento têm se direcionado à seleção de novas cultivares, visando maior produção de biomassa e maior densidade desta, com a qualidade de caldo em segundo plano.

De qualquer forma, o potencial de aproveitamento e o retorno financeiro não devem ser os únicos itens pesados para a decisão do manejo do palhiço da cana-de-açúcar, dado que sua remoção total do campo acarreta perdas na produção da cultura e na qualidade do solo. 


\section{MATERIAL E MÉTODOS}

\subsection{Caracterização da área experimental}

O experimento foi inserido em área de produção comercial de cana-de-açúcar na Usina Jalles Machado (Fazenda 66, Bloco 1), em Goianésia-GO, nas coordenadas 1507' 09.4" Sul, $48^{\circ} 53^{\prime} 52.2^{\prime \prime}$ Oeste, altitude $580 \mathrm{~m}$ (Figura 1).

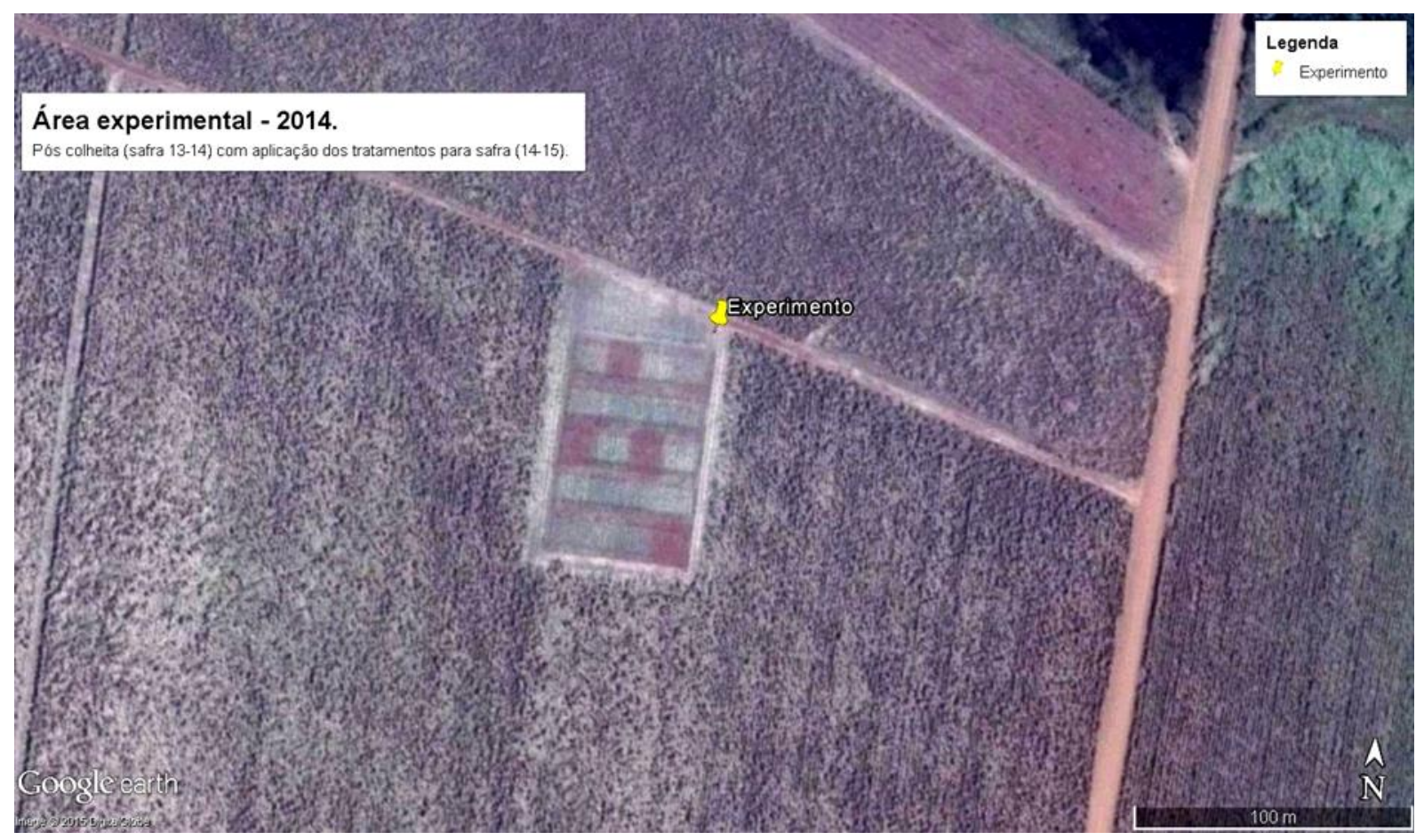

Figura 1. Área experimental, após a colheita da segunda soca (2014), com visualização clara do solo exposto no tratamento 1. Usina Jalles Machado (Fazenda 66, Bloco 1),

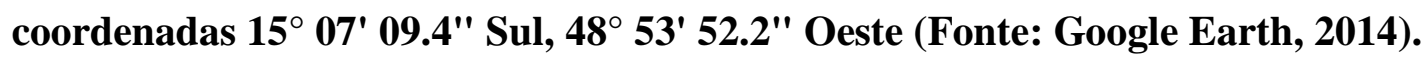

O solo da área experimental foi classificado como Latossolo Vermelho Distrófico (soma de bases na camada $20-40 \mathrm{~cm}=42 \%$ ) (EMBRAPA, 2013).

A área está inserida no domínio morfoclimático do Cerrado, e, de acordo com Köppen e Geiger (1928), apresenta clima tropical estacional de Savana Aw, com inverno seco e verão chuvoso. Os dados climatológicos da estação de Pirenópolis (INMET estação 83376), a aproximadamente 80 quilômetros (em linha reta) do experimento estão apresentados na Figura 2. 


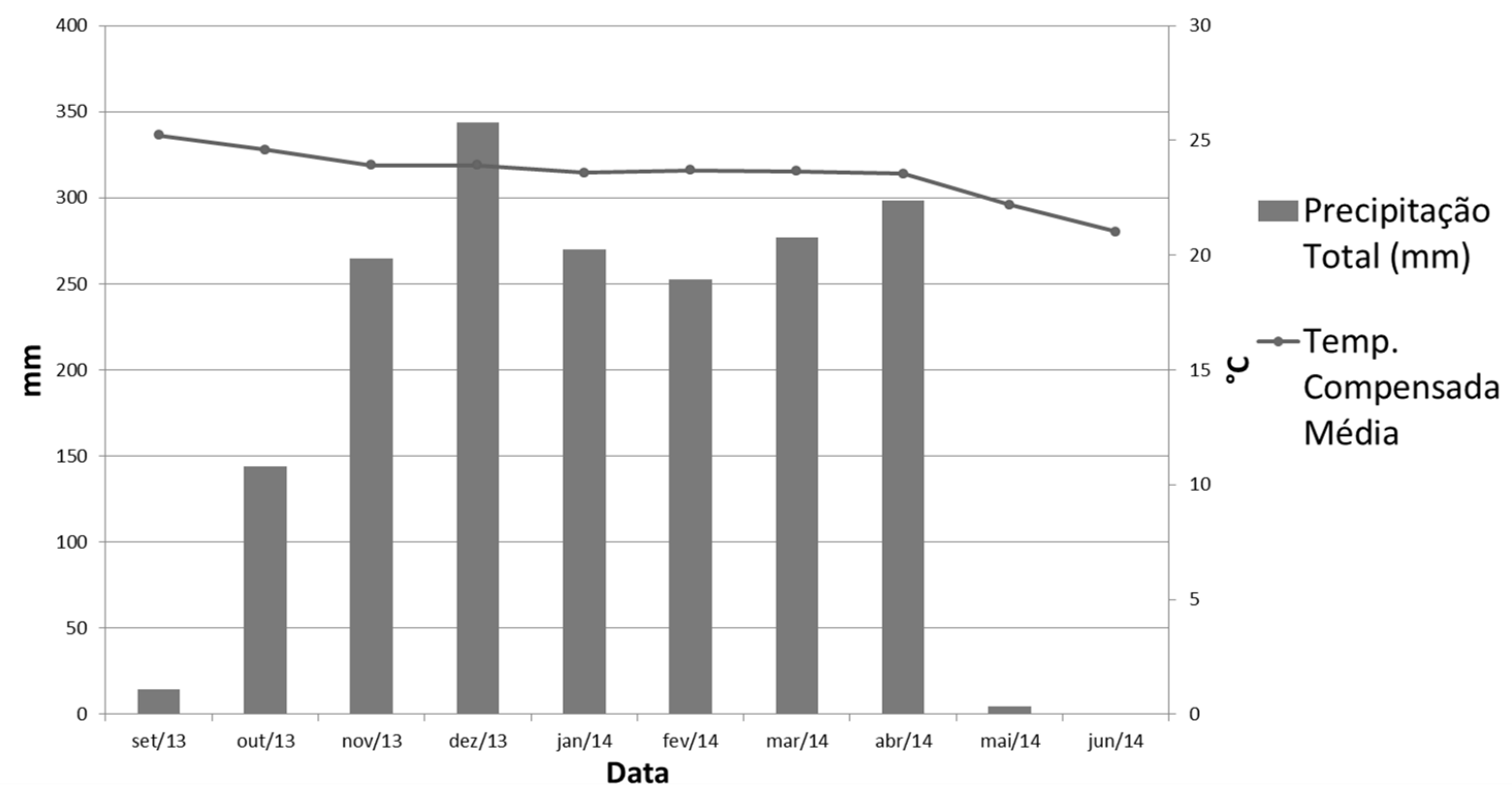

Figura 2. Distribuição pluviométrica e temperatura média no ciclo do experimento da estação INMET 83376, em Pirenópolis-GO, aprox. $80 \mathrm{~km}$ em linha reta da área experimental, para o período de condução do experimento (Fonte: INMET, 2015).

\subsection{Instalação do experimento}

A área foi implantada em 2011 e as parcelas com tratamentos em outubro de 2012, após a primeira colheita (cana planta). As coletas para as avaliações do presente trabalho foram iniciadas em agosto de 2013, em seguida à segunda colheita (primeira soca). Portanto, foi avaliado o efeito de dois anos consecutivos de aplicação dos tratamentos na cana-deaçúcar de segunda soca.

Foi cultivada a variedade de cana-de-açúcar (Saccharum spp.) IAC SP 91-1099. A cultivar apresenta alta produtividade, com produtividade $11 \%$ superior à média nacional. Também apresenta alta capacidade de acúmulo de sacarose, mesmo em cortes avançados, com produção $20 \%$ superior à média nacional. Por fim, a cultivar apresenta caráter rústico estável, permitindo o plantio com sucesso em ambientes desfavoráveis (HENRIQUE et al., 2011).

Em seguida à colheita foi realizada irrigação de salvamento para facilitar a rebrota e mitigar os efeitos do final da seca nos meses agosto e setembro. Foi também aplicada adubação comercial usual da Usina Jalles Machado, e adubação diferenciada de $\mathrm{K}$ nas parcelas onde foi removido todo o palhiço, visando isolar o efeito da mineralização desse nutriente na lavoura. 
Utilizou-se o delineamento de blocos ao acaso, com quatro repetições e cinco tratamentos, totalizando vinte parcelas. As parcelas apresentam 8 linhas cada, com $10 \mathrm{~m}$ de comprimento, e espaçamento de $1,5 \mathrm{~m}$ entrelinhas, totalizando $120 \mathrm{~m}^{2}$. As seis linhas centrais de cada parcela foram consideradas como área útil $\left(100 \mathrm{~m}^{2}\right)$. Os tratamentos foram: 1) sem palhiço residual no campo, sendo todo o palhiço removido após a colheita; 2) 25\% de palhiço residual no campo após a colheita; 3) 50\% de palhiço residual no campo após a colheita; 4) $75 \%$ de palhiço residual no campo após a colheita; 5) 100\% de palhiço residual no campo após a colheita. Para o estabelecimento dos níveis de palhiço em cada tratamento, inicialmente as parcelas foram divididas em faixas, e posteriormente foi removida a proporção desejada do palhiço para compor o tratamento, homogeneizando-se sobre a área da parcela o palhiço remanescente. $\mathrm{O}$ croqui da área experimental e a forma de preparo dos tratamentos são apresentados nas Figuras 3, 4, e 5.

\begin{tabular}{|c|c|c|c|c|c|c|c|c|c|c|c|}
\hline \multirow{8}{*}{ 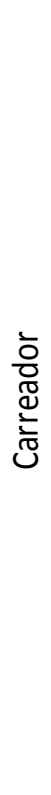 } & \multicolumn{11}{|c|}{ Estrada } \\
\hline & $\begin{array}{l}\varepsilon \\
\circ \\
\text { 음 }\end{array}$ & \multicolumn{10}{|c|}{ Canavial } \\
\hline & $\underset{\Xi}{\stackrel{E}{\sim}}$ & $\begin{array}{l}\bar{O} \\
\text { O্ }\end{array}$ & $\begin{array}{c}\text { Trat. } 2 ; \\
\text { Parcela } 1\end{array}$ & \multirow{4}{*}{ 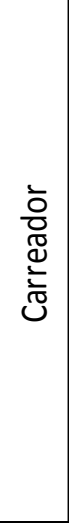 } & $\begin{array}{c}\text { Trat. } 3 ; \\
\text { Parcela } 2\end{array}$ & \multirow{4}{*}{ 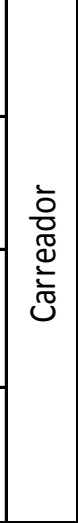 } & $\begin{array}{c}\text { Trat. 5; } \\
\text { Parcela } 3\end{array}$ & \multirow{4}{*}{ 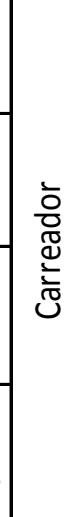 } & $\begin{array}{c}\text { Trat. } 4 ; \\
\text { Parcela } 4\end{array}$ & \multirow{4}{*}{ 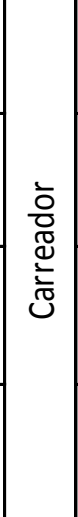 } & $\begin{array}{c}\text { Trat. } 1 ; \\
\text { Parcela } 5\end{array}$ \\
\hline & $\underset{\varepsilon}{\stackrel{\varepsilon}{\sim}}$ & $\begin{array}{l}\overline{=} \\
\text { 음 } \\
\text { 음 }\end{array}$ & $\begin{array}{c}\text { Trat. 5; } \\
\text { Parcela } 6\end{array}$ & & $\begin{array}{c}\text { Trat. 4; } \\
\text { Parcela } 7\end{array}$ & & $\begin{array}{c}\text { Trat. 1; } \\
\text { Parcela } 8\end{array}$ & & $\begin{array}{c}\text { Trat. 3; } \\
\text { Parcela } 9\end{array}$ & & $\begin{array}{c}\text { Trat. } 2 ; \\
\text { Parcela } 10\end{array}$ \\
\hline & $\underset{\xi}{\stackrel{\varepsilon}{\tau}}$ & $\begin{array}{l}\equiv \\
\text { 음 } \\
\frac{\circ}{\infty}\end{array}$ & $\begin{array}{c}\text { Trat. 1; } \\
\text { Parcela11 }\end{array}$ & & $\begin{array}{c}\text { Trat. } 3 ; \\
\text { Parcela12 }\end{array}$ & & $\begin{array}{c}\text { Trat. 5; } \\
\text { Parcela13 }\end{array}$ & & $\begin{array}{c}\text { Trat. } 2 ; \\
\text { Parcela14 }\end{array}$ & & $\begin{array}{c}\text { Trat. 4; } \\
\text { Parcela15 }\end{array}$ \\
\hline & $\underset{\varepsilon}{\stackrel{\varepsilon}{ユ}}$ & $\begin{array}{l}\geq \\
\text { 음 } \\
\frac{\circ}{\infty}\end{array}$ & $\begin{array}{c}\text { Trat. 4; } \\
\text { Parcela16 }\end{array}$ & & $\begin{array}{c}\text { Trat. } 2 ; \\
\text { Parcela17 }\end{array}$ & & $\begin{array}{c}\text { Trat. 1; } \\
\text { Parcela18 }\end{array}$ & & $\begin{array}{c}\text { Trat. 5; } \\
\text { Parcela19 }\end{array}$ & & $\begin{array}{c}\text { Trat. 3; } \\
\text { Parcela20 }\end{array}$ \\
\hline & & & $10 \mathrm{~m}$ & $5 \mathrm{~m}$ & $10 \mathrm{~m}$ & $5 \mathrm{~m}$ & $10 \mathrm{~m}$ & $5 \mathrm{~m}$ & $10 \mathrm{~m}$ & $5 \mathrm{~m}$ & $10 \mathrm{~m}$ \\
\hline & & & & & & & 70 metros & & & & \\
\hline
\end{tabular}

Figura 3. Croqui da área experimental, apresentando distribuição casualizada dos tratamentos. 

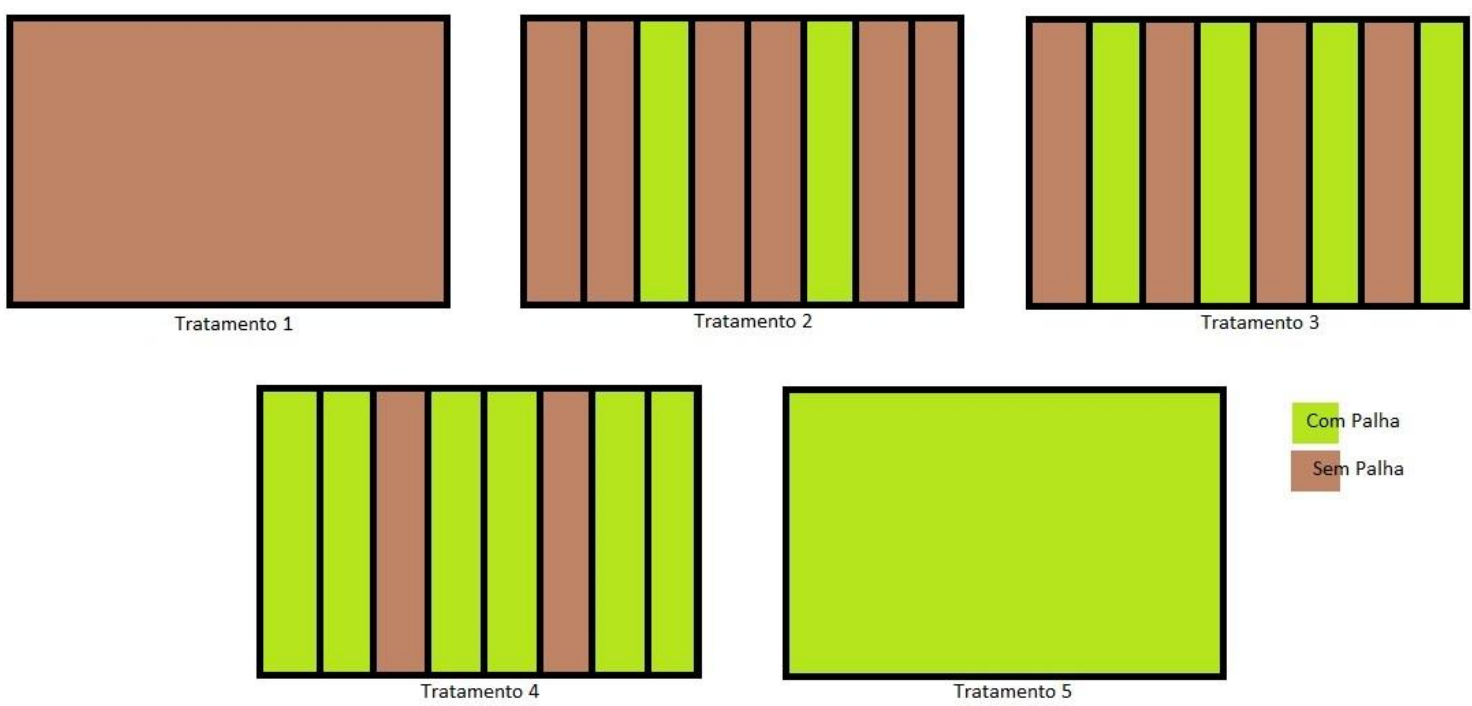

Com Palha

Sem Palha

Figura 4. Demonstrativo de como foi feita a remoção e posterior distribuição do palhiço para a composição dos tratamentos estudados.

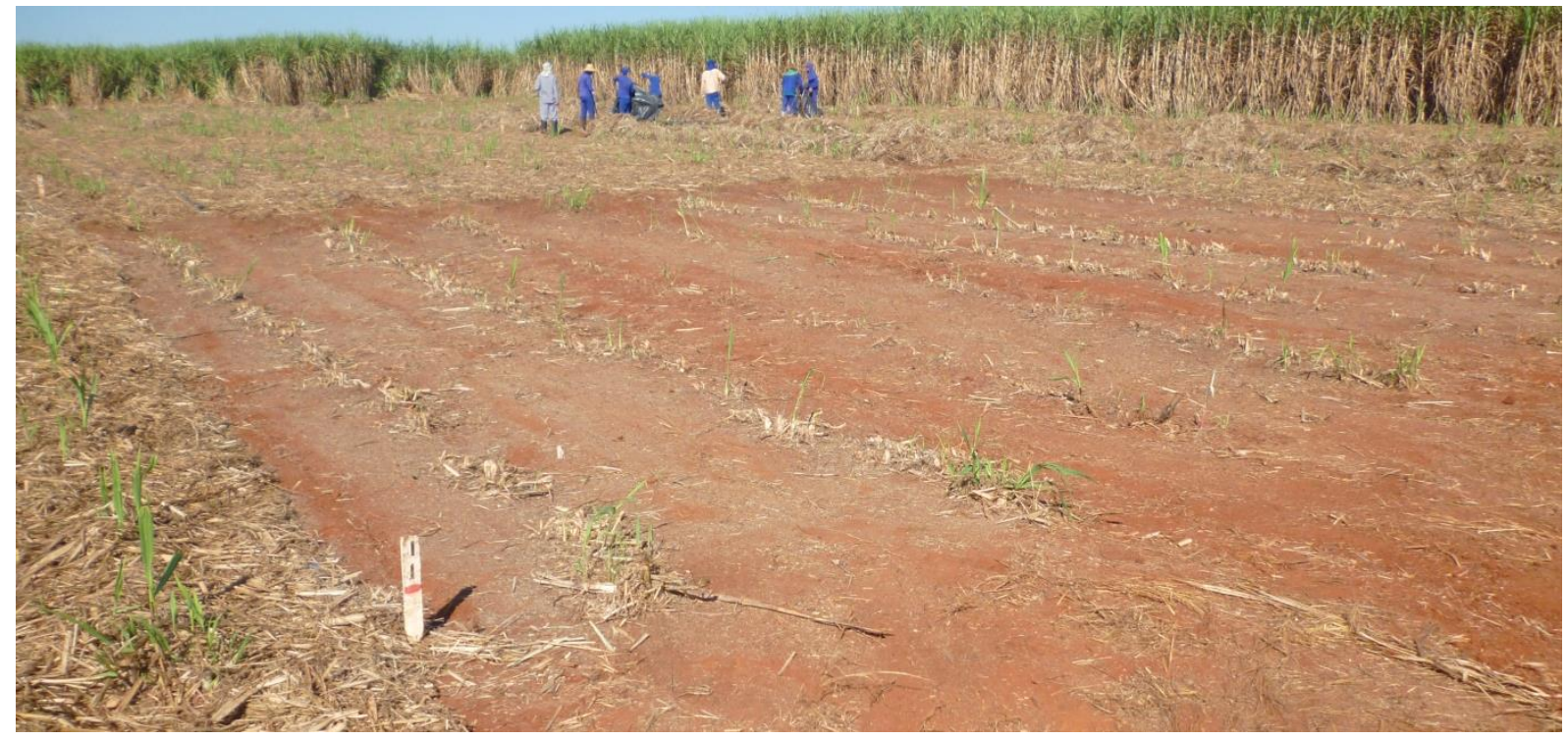

Figura 5. Parcela com remoção total do palhiço, compondo tratamento 1.

A quantidade média de palhiço remanescente pós-colheita, em cada parcela, foi obtida por amostragem de subáreas. Em cada parcela foi pesado o palhiço recolhido em cinco subáreas de 81,5x $34 \mathrm{~cm}$, medidas com auxílio de um gabarito de papelão, e foi separada uma quantidade de palhiço por bloco (homogeneizado das parcelas do bloco) para análise de macro e micronutrientes do tempo zero das avaliações. A Tabela 5 apresenta a quantidade ( $\mathrm{t}$ $\mathrm{ha}^{-1}$ ) de palhiço remanescente pós-colheita por tratamento. 
Tabela 5. Toneladas de palhiço por hectare nas parcelas do experimento.

\begin{tabular}{cc}
\hline Tratamento & Palhiço $\left(\mathbf{t ~ h a}^{-1}\right)$ - Média trat. \\
\hline 1 (0\% Palhiço) & 0,00 \\
2(25\% Palhiço) & 6,89 \\
$3(50 \%$ Palhiço $)$ & 11,44 \\
$4(75 \%$ Palhiço $)$ & 16,07 \\
$5(100 \%$ Palhiço $)$ & 25,29 \\
\hline
\end{tabular}

\subsection{Ensaio de decomposição de resíduos e liberação de nutrientes}

A instalação do ensaio de decomposição dos resíduos e mineralização de nutrientes ocorreu em setembro de 2013 e o mesmo seguiu até junho de 2014. Este ensaio foi aplicado apenas nos tratamentos 2 (25\% de palhiço residual remanescente) e 5 (100\% de palhiço residual remanescente).

A determinação da decomposição foi adaptada de Carvalho (2011). Utilizou-se o método dos litter bags (sacos de tela de nylon, com malha de $2 \mathrm{~mm}$ ) (Figura 6), cada um com 20 x $20 \mathrm{~cm}$. O palhiço foi composto de subamostras coletadas aleatoriamente nas parcelas, homogeneizadas antes do preparo dos litter bags, secas em estufa a $65^{\circ} \mathrm{C}$ por 72 horas. Após a secagem foram inseridos $20 \mathrm{~g}$ de palhada em cada litter bag.

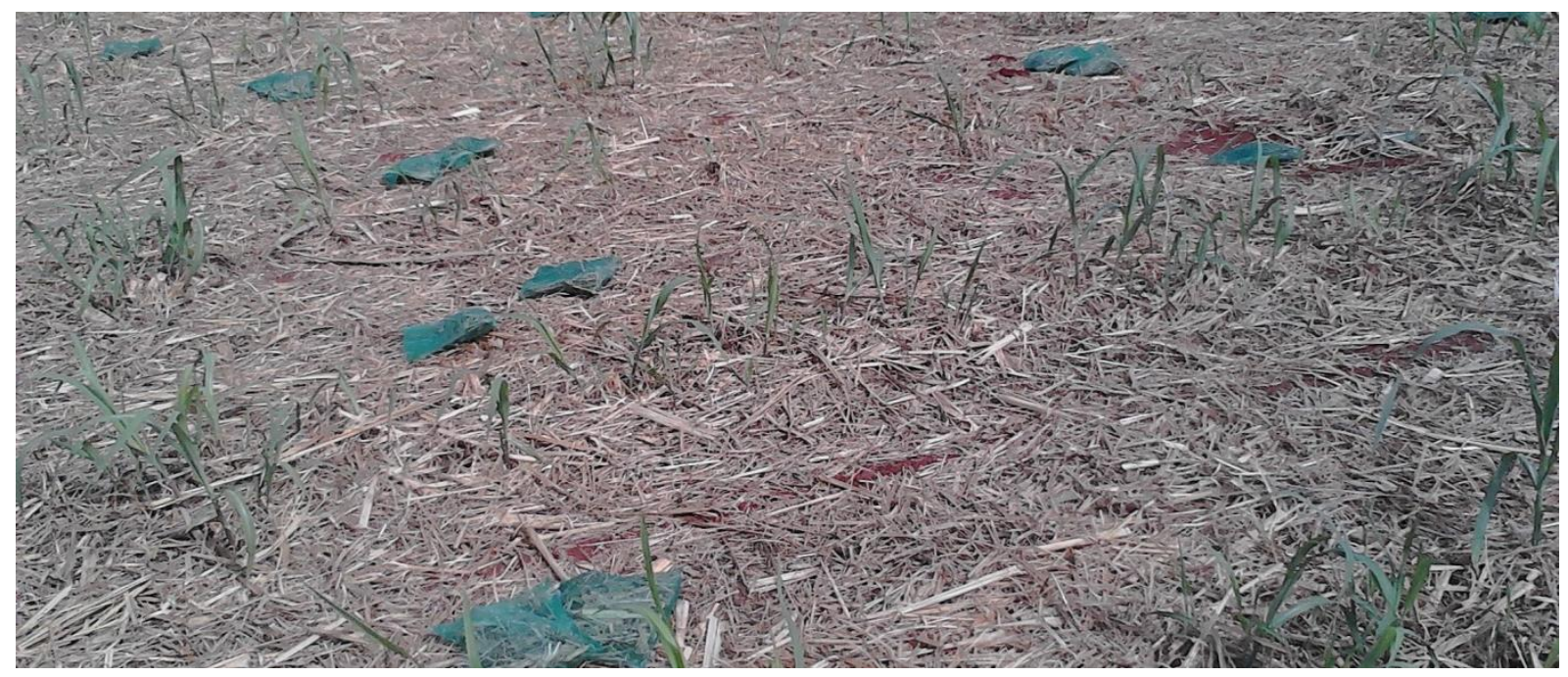

Figura 6. Litter Bags distribuídos na parcela.

Foram distribuídos 252 litter bags randomicamente nas parcelas (36 por parcela), igualmente distribuídos nas interfaces solo-palhiço e palhiço-superfície. As retiradas de campo foram feitas periodicamente, com início em novembro, porém sem seguir intervalos 
exatos devido a dificuldades logísticas. Foram feitas cinco retiradas (novembro, janeiro, março, maio, e junho), nas quais eram retirados seis litter bags por parcela, três sob, e três sobre a palha, totalizando um período de 270 dias de avaliações em junho de 2014.

Em cada coleta, foi eliminado o máximo possível de resíduos de solo e raízes de outras plantas que penetraram nos litter bags, em seguida o material remanescente foi colocado em estufa a $65^{\circ} \mathrm{C}$ por 72 horas, com nova pesagem após esse período para obtenção da massa de material seco remanescente. Após a pesagem, parte do material foi separada para as análises de macro e micronutrientes e outra parte para determinação de taxa de decomposição, segundo Santos e Whitford (1981).

Baseando-se nos dados da perda de matéria seca, obteve-se a quantidade de palhiço remanescente no solo pela diferença entre a quantidade total inicial de resíduos e a decomposição apresentada nos tratamentos.

Os dados obtidos foram ajustados ao modelo exponencial, com porcentagem de resíduos remanescentes em função do tempo (em dias) $\left(R=100 \cdot e^{-K .(t)}\right)$, da qual se extraiu a constante $(\mathrm{k})$ para o cálculo de meia vida $(h=\ln 2 / k)$ (CARVALHO, 2011; SANTOS; WHITFORD 1981).

Procedeu-se então às análises laboratoriais das amostras provenientes dos litter bags. Para as análises de macro e micronutrientes as amostras do tempo zero e de cada retirada foram encaminhas à empresa CAMPO - Agricultura e Meio Ambiente, em Paracatu-MG, onde foram analisadas de acordo com metodologias e procedimentos analíticos descritos por Malavolta et al. (1997).

\subsection{Análise foliar}

Foram coletadas amostras foliares em todas as parcelas ao final do experimento (dia 03 de junho de 2014), visando identificar os efeitos dos tratamentos no estado nutricional das plantas, via quantificação de macro e micronutrientes.

Para a amostragem foram consideradas as folhas +1 , pela classificação Kujiper (Figura 7), como folhas diagnóstico. Foram coletadas 40 folhas +1 ao acaso no centro de cada parcela. As folhas tiveram seus terços superiores e inferiores descartados, e foi removida também a nervura central. Em seguida foram lavadas com água destilada, e colocadas em estufa para secar, para posterior moagem e encaminhamento para o laboratório. 


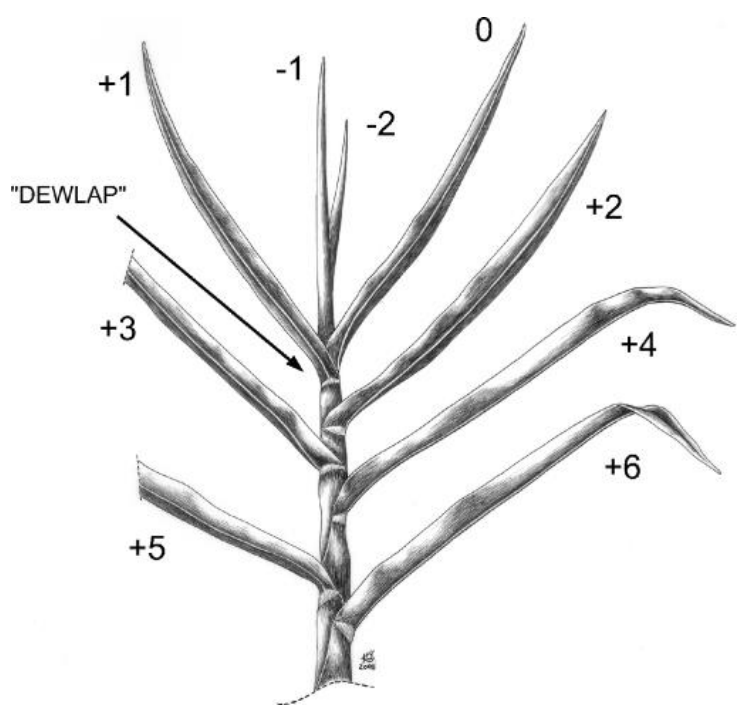

Figura 7. Esquema de numeração de folhas pelo sistema de Kuijper (DILLEWJIN, 1952).

As amostras foram encaminhadas à empresa CAMPO - Agricultura e Meio Ambiente, em Paracatu-MG, onde foram analisadas de acordo com metodologias e procedimentos analíticos descritos por Malavolta et al. (1997).

\subsection{Biometria e análises tecnológicas da cana-de-açúcar}

Foram realizadas medições dos colmos, buscando efeitos dos tratamentos sobre as medidas da cana-de-açúcar, seguindo metodologia adaptada de Landell e Bressiani (2010).

Doze plantas foram selecionadas ao acaso, na porção central das parcelas. Foram medidas altura e diâmetro, bem como a massa das plantas. A altura a planta foi medida da base do solo à inserção da folha +1 , com fita métrica. $\mathrm{O}$ diâmetro foi medido na altura do terço inferior da planta (Figura 8). O peso de 12 colmos foi obtido com balança levada ao campo. As medidas geraram médias por parcela.

As análises de fibra, Brix do caldo, pureza do caldo, e açúcares totais recuperáveis foram executadas pela Usina Jalles Machado, segundo metodologia corrente do CONSECANA (2006). 


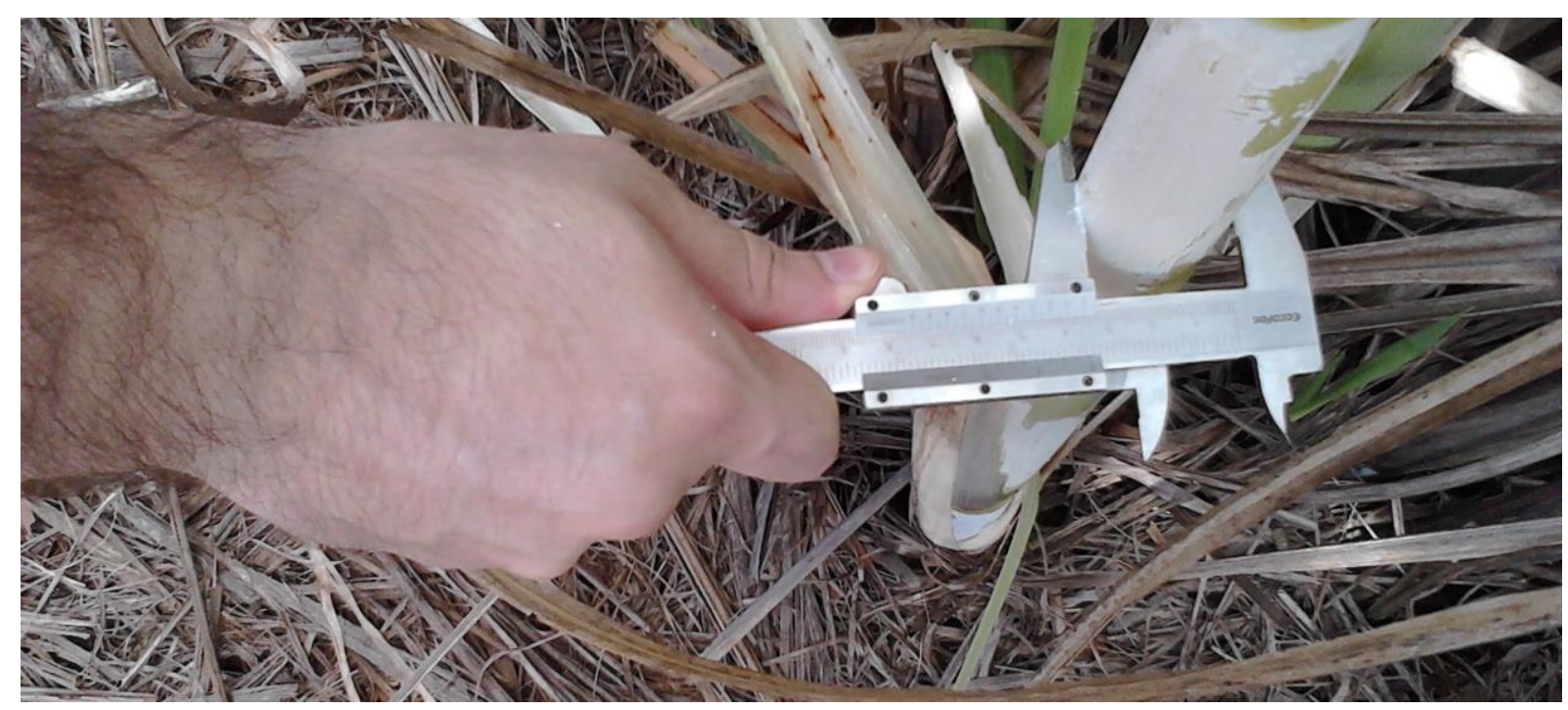

Figura 8. Medição do diâmetro no terço inferior da planta, na porção central do entrenó.

\subsection{Produtividade}

O experimento foi colhido mecanicamente, com colhedoras John Deere 3520, com auxílio de caminhões transbordo VW 16.190 (Figura 9) equipados com células de carga, cedidos pelo Centro de Tecnologia Canavieira (CTC). A TCH (tonelada de colmos por hectare) foi obtida com auxílio das células de carga presentes nos caminhões, e descartou-se as medidas obtidas na primeira e na última linha de cada parcela (bordaduras), considerando apenas a área útil do experimento, na aferição da produtividade.

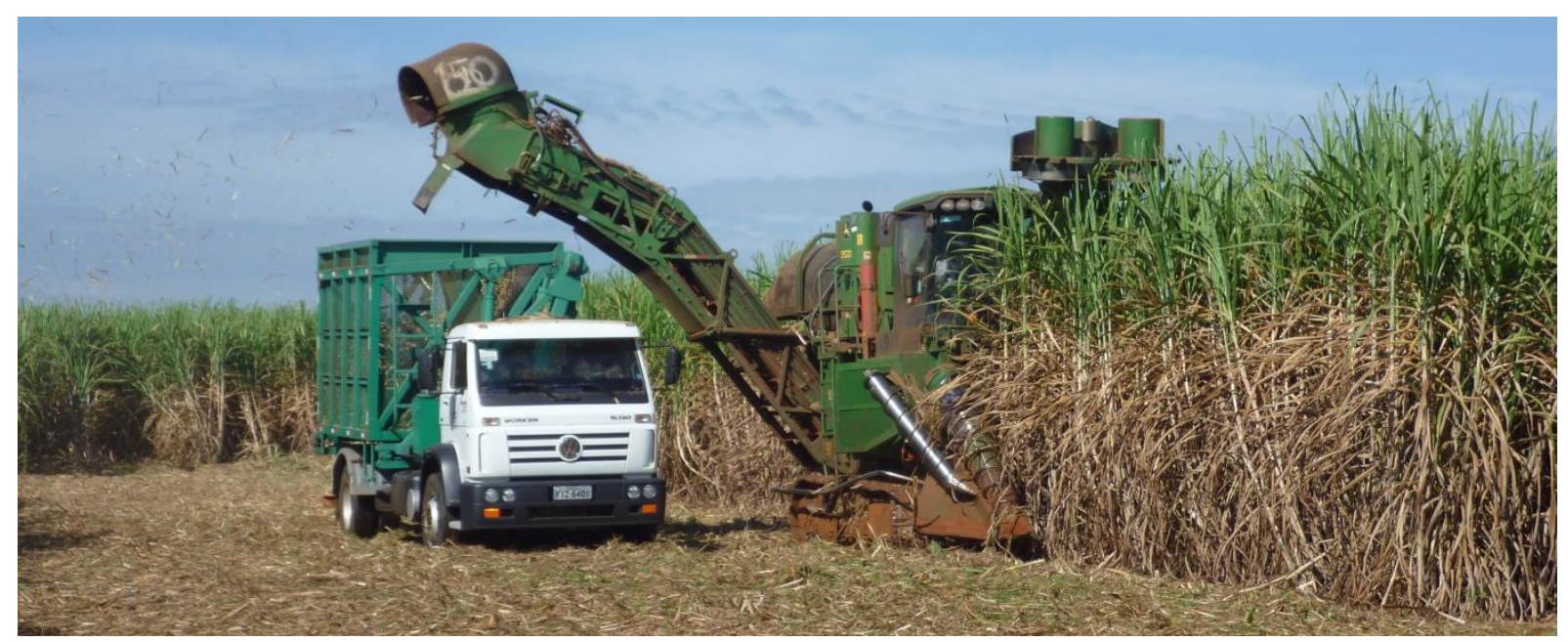

Figura 9. Procedimento de colheita mecânica na Usina Jalles Machado, com auxílio de transbordo equipado com células de carga. 


\subsection{Análises estatísticas}

Primeiramente analisou-se cada série de dados quanto a sua distribuição. Os dados que apresentaram distribuição normal foram submetidos à análise de variância (ANOVA), e em seguida tiveram suas médias comparadas pelo teste de Tukey, a 5\% de significância. As séries de dados que não apresentaram distribuição normal foram submetidas ao teste de KruskalWallis com comparações múltiplas (BANZATTO; KRONKA, 2006).

Para análise de variância e teste de Tukey foi utilizado o software ASSISTAT 7.7 (SILVA, 2012), ao passo que o software ACTION 2.9 (EQUIPE ESTATCAMP, 2014) foi usado para o teste de Kruskal-Wallis. 


\section{RESULTADOS E DISCUSSÃO}

\subsection{Ensaio de decomposição e aporte de nutrientes dos resíduos para o solo}

\subsubsection{Decomposição}

As quantidades médias de palhiço equivalentes a cada tratamento foram apresentadas na metodologia. Foram observadas, respectivamente, para os tratamentos 1, 2, 3, 4, e 5, as seguintes quantidades de palhiço residual remansescente: 0,00 t.ha ${ }^{-1} ; 6,89$ t.ha $^{-1} ; 11,44$ t.ha ${ }^{-1}$; 16,07 t.ha' ${ }^{-1}$; e 25,29 t.ha ${ }^{-1}$.

Os dados da decomposição do palhiço, nos tratamentos 2 (25\% palhiço) e 5 (100\% palhiço), ao longo do período avaliado estão apresentados na Figura 10.

\section{Palhiço Remanescente (\%)}

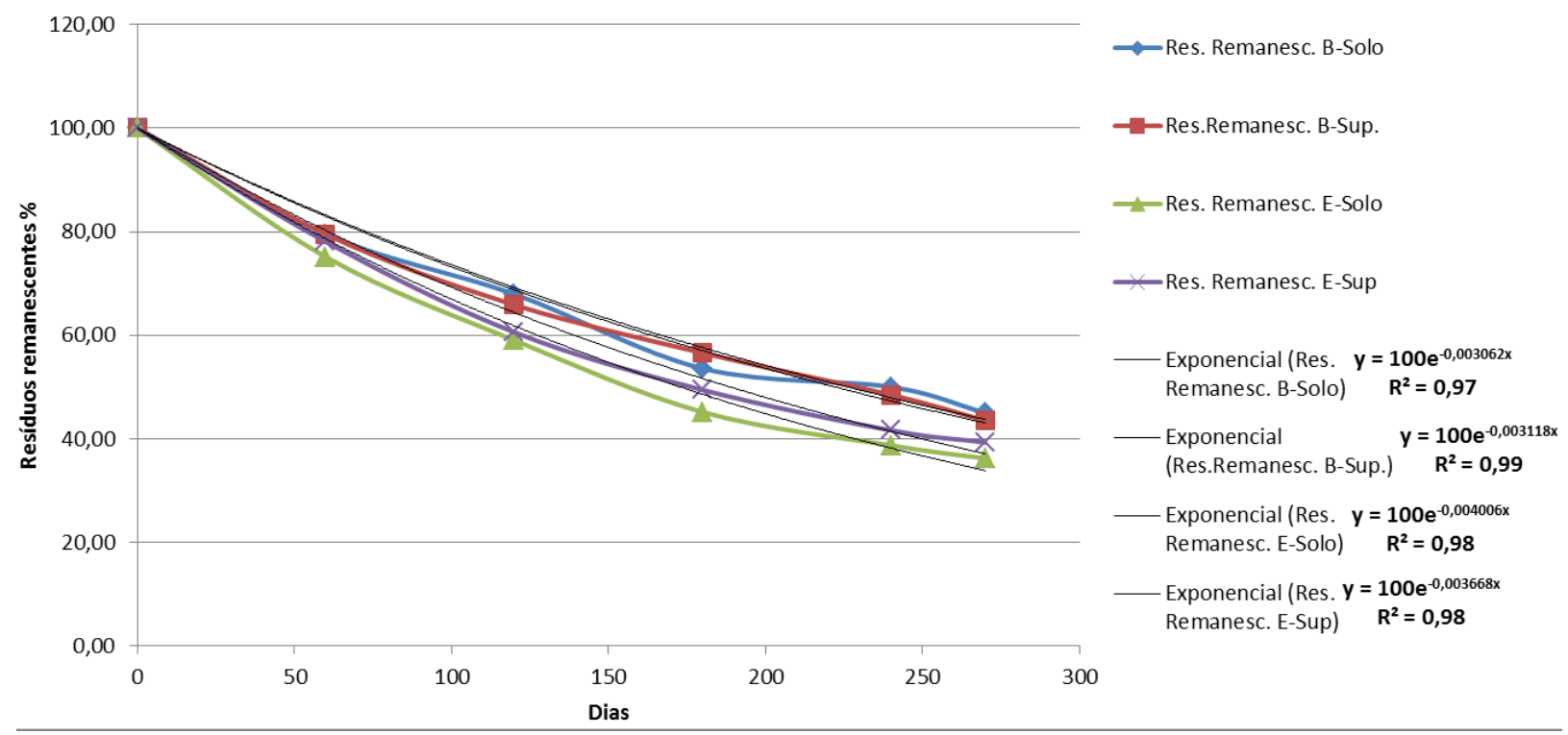

Figura 10. Curvas de decomposição (\%) do palhiço ao longo do tempo e respectivas linhas de tendência exponenciais, nos tratamentos 2 (25\% palhiço) e 5 (100\% palhiço), nas interfaces solo-palhiço e palhiço-superfície.

Houve considerável decomposição dos resíduos no período avaliado, sendo que ao final dos 270 dias avaliados, em média, aproximadamento $60 \%$ dos resíduos haviam sido decompostos. $\mathrm{O}$ aporte médio de material decomposto no período foi de 3,75 toneladas no tratamento 2 e 15,84 toneladas para o tratamento 5 .

Os elevados valores de $r^{2}$ indicam alta representabilidade dos modelos exponenciais aplicados para as curvas de decaimento do palhiço, podendo-se prever com confiabilidade o comportamento da decomposição do palhico em tempos além dos avaliados. 
Com as equações obtidas dos modelos exponenciais aplicados, foram obtidas as constantes k para cada tratamento aplicado, obtendo-se em seguida os valores de meia vida. Os tempos médios de meia vida do palhiço nos tratamentos e posições, estão apresentadas na Tabela 6.

Tabela 6. Tempos médios de meia vida do palhiço, nos tratamentos 2 e 5 , nas interfaces palhiço-solo e palhiço-superfície.

\begin{tabular}{|c|c|c|}
\hline \multicolumn{3}{|c|}{ Meia vida (dias) } \\
\hline \multirow{2}{*}{ Tratamento } & \multicolumn{2}{|c|}{ Posição do palhiço } \\
\hline & Interface solo-palhiço & Interface palhiço-superfície \\
\hline $2(25 \%$ palhiço $)$ & $226 a$ & $231 \mathrm{a}$ \\
\hline $5(100 \%$ palhiço $)$ & $173 b$ & $188 \mathrm{~b}$ \\
\hline $\mathbf{F}$ & $251,55^{* *}$ & $13,60^{*}$ \\
\hline DMS & 10,63 & 36,45 \\
\hline $\mathrm{CV}(\%)$ & 2,36 & 7,72 \\
\hline \multicolumn{3}{|c|}{ Meia vida (dias) } \\
\hline \multirow{2}{*}{ Posição do palhiço } & \multicolumn{2}{|c|}{$\begin{array}{ll}\text { Tratamento } \\
\end{array}$} \\
\hline & $2(25 \%$ palhiço $)$ & $5(100 \%$ palhiço $)$ \\
\hline Interface solo-palhiço & $226 a$ & $173 a$ \\
\hline Interface palhiço-superfície & $231 \mathrm{a}$ & $188 \mathrm{a}$ \\
\hline $\mathbf{F}$ & $2,06 \mathrm{~ns}$ & $6,22 \mathrm{~ns}$ \\
\hline DMS & 20,17 & 19,13 \\
\hline $\mathrm{CV}(\%)$ & 1,83 & 4,69 \\
\hline
\end{tabular}

Os resultados de meia vida e reciclagem são compatíveis com os encontrados em outros trabalhos publicados (COELHO, 2012). O longo tempo de meia vida infere que os efeitos do palhiço sobre o ambiente de produção devem se apresentar pelo menos após um ano da colheita e deposição do palhiço no campo, dessa forma, deve ser esperado um efeito no longo prazo quando se decide deixar o palhiço no campo e a quantidade a ser deixada.

Não houve diferença significativa para meia vida entre as interfaces de posicionamentos do litter bags para nenhum dos dois tratamentos aplicados. Por outro lado, em ambas as interfaces houve diferenças entre os tratamentos, o que indica que a maior influência na meia vida dos resíduos vem da quantidade de palhiço, e não da posição desse palhiço na massa de resíduos.

Tais dados contrastam com aqueles encontrados por Santana et al. (2011), que analisando a decomposição de biomassa de folhas de cana de açúcar na região Nordeste brasileira, encontrou diferenças significativas entre as decomposições dos resíduos ao longo 
do tempo em posicionamentos dos resíduos na superfície (perdas de 29,2\% após três meses) e na subsuperfície (perdas de 42,7\% após três meses). Entretanto, é importante ressaltar que em tal trabalho o tratamento subsuperficial tratava-se de enterrar os resíduos a $15 \mathrm{~cm}$ de profundidade no solo, condição deveras diferente da encontrada no presente trabalho.

As médias das decomposições (\%) por tratamento e por posicionamento dos litter bags estão apresentados na Tabela 7.

Tabela 7. Médias de decomposição do palhiço (\%), nos tratamentos 2 (25\% palhiço) e 5 (100\% palhiço), nas interfaces solo-palhiço e palhiço-superfície.

\begin{tabular}{|c|c|c|}
\hline \multicolumn{3}{|c|}{ Decomposição (\%) } \\
\hline \multirow{2}{*}{ Tratamento } & \multicolumn{2}{|c|}{ Posição do palhiço } \\
\hline & Interface solo-palhiço & Interface palhiço-superfície \\
\hline $2(25 \%$ palhiço $)$ & $54,96 b$ & $54,62 \mathrm{a}$ \\
\hline $5(100 \%$ palhiço $)$ & $63,76 a$ & $60,65 \mathrm{a}$ \\
\hline $\mathbf{F}$ & $20,76^{*}$ & $3,03 \mathrm{~ns}$ \\
\hline DMS & 6,14 & 11,03 \\
\hline $\mathrm{CV}(\%)$ & 4,60 & 8,51 \\
\hline \multicolumn{3}{|c|}{ Decomposição (\%) } \\
\hline \multirow{2}{*}{ Posição do palhiço } & \multicolumn{2}{|c|}{ Tratamento } \\
\hline & $2(25 \%$ palhiço $)$ & $5(100 \%$ palhiço $)$ \\
\hline Interface solo-palhiço & $54,96 \mathrm{a}$ & $63,76 a$ \\
\hline Interface palhiço-superfície & $54,62 \mathrm{a}$ & $60,65 \mathrm{a}$ \\
\hline $\mathbf{F}$ & $0,04 \mathrm{~ns}$ & $2,84 \mathrm{~ns}$ \\
\hline DMS & 4,85 & 5,85 \\
\hline $\mathrm{CV}(\%)$ & 3,94 & 4,18 \\
\hline
\end{tabular}

Médias seguidas pela mesma letra na coluna não diferem entre si pelo teste de Tukey a 5\%.

* Valores significativos a $5 \%$ de probabilidade pelo teste $\mathrm{F}$.

ns Valores não significativos a 5\% de probabilidade pelo teste $\mathrm{F}$.

Não foram observadas diferenças significativas entre as posições do palhiço (interface solo-palhiço e interface palhiço-atmosfera) em ambos os tratamentos avaliados quanto à decomposição de resíduos, bem como também não houve diferenças significativas entre os tratamentos na posição interface palhiço-superfície.

Quanto ao palhiço em contato direto com o solo, na interface solo-palhiço, houve decomposição mais acelerada no tratamento 5. A maior quantidade de palhiço no tratamento 5 retém mais umidade, propiciando ambiente mais favorável à ação de organismos atuantes na decomposição de resíduos. Dessa forma, o palhiço no tratamento 5 é mais propício à a disponibilização de nutrientes ao longo do tempo. 
Os menores tempos de meia vida do tratamento $5 \mathrm{em}$ ambos posicionamentos do palhiço denota vantagem do tratamento no que toca a velocidade da decomposição dos resíduos, entretanto, a análise estatística de comparação das médias de decomposição ao final do ensaio mostra que só houve diferença significativa entre os tratamentos no palhiço posicionado na interface palhiço-solo.

Isso pode ser consequência da semelhança de ambientes entre os dois tratamentos na interface palhiço-superfície, dado que o alto aporte de massa do tratamento 5 afeta consideravelmente o ambiente abaixo do palhiço, e não afeta tanto o ambiente da superfície. Essa igualdade de resultados na interface palhiço-superfície pode indicar que com o avanço do tempo as taxas de decomposição na interface palhiço-superfície se igualem entre os tratamentos.

\subsubsection{Mineralização de nutrientes}

Os teores de macro e micronutrientes encontrados no palhiço coletado no tempo zero estão apresentados na Tabela 8.

Tabela 8. Teores médios iniciais de macro e micronutrientes no palhiço residual da colheita da cana-de-açúcar.

\begin{tabular}{|c|c|c|c|c|c|c|}
\hline \multirow{3}{*}{ Tratamento } & \multicolumn{6}{|c|}{ Macronutrientes } \\
\hline & $\mathbf{N}$ & $\mathbf{P}$ & $\mathbf{K}$ & $\mathbf{C a}$ & Mg & $\mathbf{S}$ \\
\hline & \multicolumn{6}{|c|}{ 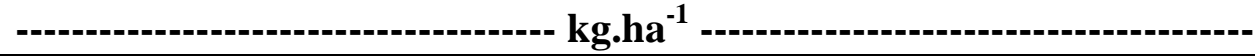 } \\
\hline $\begin{array}{l}2(25 \% \\
\text { palhiço) }\end{array}$ & 19,76 & 3,23 & 38,95 & 12,74 & 16,41 & 6,84 \\
\hline \multirow[t]{2}{*}{$\begin{array}{l}5(100 \% \\
\text { palhiço) }\end{array}$} & 76,09 & 12,09 & 143,93 & 48,46 & 61,10 & 25,54 \\
\hline & \multicolumn{6}{|c|}{ Micronutrientes } \\
\hline \multirow[t]{2}{*}{ Tratamento } & $\mathbf{B}$ & $\mathbf{Z n}$ & \multicolumn{2}{|c|}{$\mathrm{Fe}$} & Mn & $\mathbf{C u}$ \\
\hline & \multicolumn{6}{|c|}{ 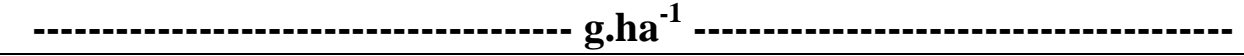 } \\
\hline $\begin{array}{l}2(25 \% \\
\text { palhiço) }\end{array}$ & 193,91 & 70,40 & 23 & & 699,69 & 50,81 \\
\hline $\begin{array}{l}5(100 \% \\
\text { palhiço) }\end{array}$ & 556,76 & 260,14 & 80 & & 2574,07 & 182,67 \\
\hline
\end{tabular}

Tais dados demonstram o potencial do palhiço como fornecedor de nutrientes para o solo à medida que sua decomposição avança. Os valores são consideravelmente próximos aos valores de extração por produção de 100 toneladas de colmos apresentados por Orlando Filho (1993), o que faz pensar que em uma situação ideal de total decomposição dos resíduos no 
período do ciclo da lavoura, na soca seguinte grande parte das necessidades nutricionais seriam supridas pelo palhiço da soca dois anos anterior. Entretando, não há tal realidade ideal quanto à mineralização dos nutrientes do palhiço de cana de açúcar.

Os dados de nutrientes procedentes do palhiço disponibilizados (mineralizados) durante o período avaliado estão apresentados na Tabela 9.

Tabela 9. Quantidades médias de macro e micronutrientes mineralizados do palhiço residual da colheita da cana-de-açúcar ao final de $\mathbf{2 7 0}$ dias de decomposição.

\begin{tabular}{|c|c|c|c|c|c|c|}
\hline \multirow{3}{*}{ Tratamento } & \multicolumn{6}{|c|}{ Macronutrientes } \\
\hline & $\mathbf{N}$ & $\mathbf{P}$ & $\mathbf{K}$ & $\mathbf{C a}$ & Mg & $\mathbf{S}$ \\
\hline & \multicolumn{6}{|c|}{ 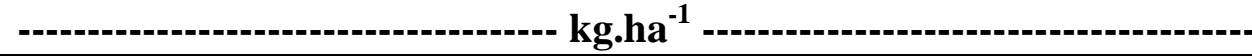 } \\
\hline $\begin{array}{l}2(25 \% \\
\text { palhiço) }\end{array}$ & $-4,70$ & 0,70 & 37,81 & 3,59 & 10,19 & 3,59 \\
\hline \multirow[t]{2}{*}{$\begin{array}{l}5(100 \% \\
\text { palhiço) }\end{array}$} & $-2,45$ & 3,45 & 139,26 & 18,16 & 40,50 & 14,95 \\
\hline & \multicolumn{6}{|c|}{ Micronutrientes } \\
\hline \multirow[t]{2}{*}{ Tratamento } & $\mathbf{B}$ & $\mathbf{Z n}$ & \multirow{2}{*}{\multicolumn{2}{|c|}{$\mathbf{F e}$}} & Mn & $\mathbf{C u}$ \\
\hline & \multicolumn{5}{|c|}{------------------------------------- g.ha' } & \\
\hline $\begin{array}{l}2(25 \% \\
\text { palhiço) }\end{array}$ & 151,58 & $-29,90$ & -13 & & 117,21 & $-36,70$ \\
\hline $\begin{array}{l}5(100 \% \\
\text { palhiço) }\end{array}$ & 449,55 & $-43,70$ & -36 & & 746,13 & $-110,47$ \\
\hline
\end{tabular}

Há que se observar que $\mathrm{N}, \mathrm{Zn}, \mathrm{Fe}$, e $\mathrm{Cu}$ tiverem suas quantidade (por hectare no palhiço) aumentadas no período avaliado. Tal fato pode ocorrer pela contaminação dos litter bags por pattículas de solo, raízes, e microrganismos que entram nos litter bags enquanto no campo. Entretanto, tal contaminação é minimizada pelo tratamento dos litter bags após a coleta dos mesmo, e mesmo quando ocorre seu impacto é o mesmo a todos os nutrientes.

Os valores acumulados de $\mathrm{Zn}$ e $\mathrm{Cu}$ são muito baixos, e portanto sesíveis a interferências externas. É difícil a identificação da causa de tal aumento de concentração, se decorrente de contaminação dos resíduos por solo ou imobilização dos nutrientes. O Fe, por sua vez, é presente em Latossolos de Cerrado em altíssimas concentrações, o que pode ter acarretado o aumento em sua quantidade nos resíduos, especialmente nos litter bags em contato com o solo.

Para o N, uma possível explicação para tal aumento na sua quantidade por hectare é o fato do nutriente ser altamente recalcitrante, por se encontrar principalmente nos componentes estruturais das plantas, e ter sua decomposição fortemente correlacionada com o início do 
decaimento da lignina nas plantas, que está entre os últimos componentes estruturais a sofrer efeitos da decomposição (COELHO, 2012). Em estudo de decomposição de pastagem Bahia (gramínea, C/N alta), Freire et al. (2010) concluíram que aplicação de $\mathrm{N}$ acelera a decomposição dos resíduos e mineralização de nutrientes em serrapilheira de bosque de sabiá, entretanto, observaram que a mineralização do $\mathrm{N}$ era baixa, e havia alta imobilização do nutriente.

Os demais nutrientes tiveram aportes consideráveis no período avaliado, muitos deles equivalentes a uma considerável fração das quantidades extraídas por produção de 100 toneladas de colmos apresentados por Orlando Filho (1993). Merece destaque o aporte de K provindo do palhiço. O nutriente não se concentra em compostos estruturais das plantas, de forma que sua mineralização se dá de forma muito rápida, estando disponível logo para a soca seguinte, no caso da cana-de-açúcar.

Tal entrada de nutrientes pode garantir economia na produção, em especial na adubação de correção e manutenção. Apesar da não observação de efeitos significativos sobre a fertilidade do solo em estudos de curto prazo (CASTRO GAVA, 2001), no longo prazo a adição de material orgânico à lavoura altera as propriedades químicas e de fertilidade do solo, corroborando com a idéia de que, no longo prazo, a manutenção do palhiço no sistema é benéfica à lavoura (CANELLAS et al., 2003). Andrade et al. (2011), em ensaio de 5 anos comparando os efeitos da colheita da cana crua e da colheita com queima nos custos de produção e reposição de nutrientes, observaram que a queima do palhiço resultou em perdas de solo e nutrientes nas áreas queimadas, e o custo de reposição de nutrientes foi 30\% superior ao da área colhida crua.

Dessa forma, um planejamento preciso, com visão ampla dos benefícios do palhiço residual da colheita para a lavoura da cana-de-açúcar, bom como para o solo, é imprescindível para o sucesso dos produtores em tempos que exigem altíssimas eficiências dos processos produtivos.

\subsection{Análise foliar}

Os valores de foliares para macro e micronutrientes estão apresentados nas Tabelas 10 e 11, respectivamente. $\mathrm{N}, \mathrm{K}, \mathrm{Mg}, \mathrm{S}, \mathrm{Zn}, \mathrm{Fe}$, e $\mathrm{Mn}$ apresentaram distribuição normal, e portanto foram avaliados com o teste de Tukey. Já os dados de $\mathrm{P}, \mathrm{Ca}, \mathrm{B}, \mathrm{e} \mathrm{Cu}$ não apresentaram distribuição normal, e tiveram suas médias comparadas pelo teste de KruskalWallis com comparações múltiplas. 
Tabela 10. Valores foliares para macronutrientes em cana-de-açúcar sob 5 tratamentos (1 a 5) de remoção de palhiço residual pós-colheita.

\begin{tabular}{ccccccc}
\hline Tratamento & $\mathbf{N}$ & $\mathbf{P}$ & $\mathbf{K}$ & $\mathbf{C a}$ & $\mathbf{M g}$ & $\mathbf{S}$ \\
\hline $\mathbf{1}(\mathbf{0 \%}$ palhiço) & $14,27 \mathrm{a}$ & $1,77 \mathrm{NS}$ & $9,80 \mathrm{a}$ & $3,02 \mathrm{NS}$ & $2,47 \mathrm{a}$ & $1,27 \mathrm{ab}$ \\
$\mathbf{2}(\mathbf{2 5 \%}$ palhiço) & $13,92 \mathrm{a}$ & $1,77 \mathrm{NS}$ & $11,40 \mathrm{a}$ & $2,55 \mathrm{NS}$ & $2,42 \mathrm{a}$ & $1,22 \mathrm{~b}$ \\
$\mathbf{3}(\mathbf{5 0 \%}$ palhiço) & $12,87 \mathrm{a}$ & $1,75 \mathrm{NS}$ & $9,37 \mathrm{a}$ & $2,25 \mathrm{NS}$ & $2,20 \mathrm{a}$ & $1,22 \mathrm{~b}$ \\
$\mathbf{4}(\mathbf{7 5 \%}$ palhiço) & $13,12 \mathrm{a}$ & $1,85 \mathrm{NS}$ & $10,75 \mathrm{a}$ & $2,50 \mathrm{NS}$ & $2,37 \mathrm{a}$ & $1,25 \mathrm{ab}$ \\
$\mathbf{5}(\mathbf{1 0 0 \%}$ palhiço) & $14,15 \mathrm{a}$ & $1,90 \mathrm{NS}$ & $10,15 \mathrm{a}$ & $2,72 \mathrm{NS}$ & $2,50 \mathrm{a}$ & $1,42 \mathrm{a}$ \\
\hline $\mathbf{F}^{\mathbf{1}}$ & $0,96 \mathrm{~ns}$ & 2,470 & $2,15 \mathrm{~ns}$ & 4,152 & $1,11 \mathrm{~ns}$ & $4,0^{*}$ \\
DMS (5\%) & 2,90 & 11,74 & 2,44 & 11,74 & 0,50 & 0,18 \\
$\mathbf{C V}(\mathbf{\%})^{\mathbf{2}}$ & 9,41 & 0,650 & 10,55 & 0,385 & 9,44 & 6,54 \\
\hline
\end{tabular}

Médias seguidas pela mesma letra na coluna não diferem entre si pelo teste de Tukey a 5\%.

NS Valores sem diferença entre si com significância a 5\% de pelo teste de Kruskal-Wallis.

ns Valores não significativos a $5 \%$ de probabilidade pelo teste $\mathrm{F}$.

* Valores significativos a 5\% de probabilidade pelo teste $\mathrm{F}$.

1 Valores nessa coluna significam valores de F para Tukey, ou qui-quadrado para Kruskal-Wallis.

2 Valores nessa coluna significam valores de CV (\%) para Tukey, ou P-valor para Kruskal-Wallis.

Tabela 11. Valores foliares para micronutrientes em cana-de-açúcar sob 5 tratamentos (1 a 5) de remoção de palhiço residual pós-colheita.

\begin{tabular}{|c|c|c|c|c|c|}
\hline \multirow{2}{*}{ Tratamento } & B & $\mathbf{Z}$ & $\mathbf{F e}$ & Mn & $\mathbf{C u}$ \\
\hline & \multicolumn{5}{|c|}{ 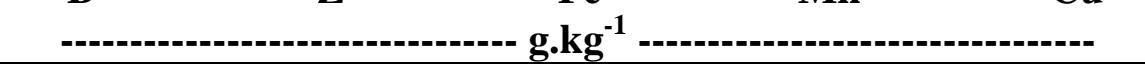 } \\
\hline $1(0 \%$ palhiço) & $5,25 \mathrm{NS}$ & $22,75 a$ & $389,00 \mathrm{a}$ & $56,25 \mathrm{a}$ & $5,00 \mathrm{NS}$ \\
\hline 2 (25\% palhiço) & $4,75 \mathrm{NS}$ & $20,25 a$ & $347,75 a$ & $67,00 \mathrm{a}$ & $5,00 \mathrm{NS}$ \\
\hline 3 (50\% palhiço) & $6,00 \mathrm{NS}$ & $21,50 \mathrm{a}$ & $355,00 \mathrm{a}$ & $54,25 \mathrm{a}$ & $5,00 \mathrm{NS}$ \\
\hline 4 (75\% palhiço) & $5,50 \mathrm{NS}$ & $21,75 \mathrm{a}$ & $376,00 \mathrm{a}$ & $57,50 \mathrm{a}$ & $4,75 \mathrm{NS}$ \\
\hline 5 (100\% palhiço) & $4,75 \mathrm{NS}$ & $24,00 \mathrm{a}$ & $357,00 \mathrm{a}$ & $62,50 \mathrm{a}$ & $5,25 \mathrm{NS}$ \\
\hline $\mathrm{F}^{1}$ & 11,742 & $1,92 \mathrm{~ns}$ & $0,29 \mathrm{~ns}$ & $0,66 \mathrm{~ns}$ & 11,742 \\
\hline DMS $(5 \%)$ & 2,626 & 4,57 & 141,58 & 28,66 & 0,357 \\
\hline $\mathrm{CV}(\%)^{2}$ & 0,622 & 9,21 & 17,20 & 21,36 & 0,985 \\
\hline
\end{tabular}

Médias seguidas pela mesma letra na coluna não diferem entre si pelo teste de Tukey a 5\%.

NS Valores sem diferença entre si com significância a 5\% de pelo teste de Kruskal-Wallis.

ns Valores não significativos a 5\% de probabilidade pelo teste $\mathrm{F}$.

1 Valores nessa coluna significam valores de $\mathrm{F}$ para Tukey, ou qui-quadrado para Kruskal-Wallis.

2 Valores nessa coluna significam valores de CV (\%) para Tukey, ou P-valor para Kruskal-Wallis.

Dentre os diversos nutrientes avaliados só houve diferença significativa entre os tratamentos para o enxofre (Tabela 10), entretanto não é possível concluir se o efeito é proveniente do palhiço, visto que os tratamentos 5, 4, e 1 não apresentaram diferenças entre si.

A falta de resposta da planta aos tratamentos, mesmo com considerável mineralização de nutrientes do palhiço, pode ser efeito do longo tempo de decomposição dos resíduos e da mobilização dos nutrientes. Prado e Pancelli (2008) observaram que o palhiço atrasa a resposta da cultura a alguns nutrientes, entre eles o nitrogênio. Em seu estudo, os autores identificaram resposta da cultura aos nutrientes, quando colhida mecanicamente e sem 
queima, somente a partir da segunda soca. O mesmo foi observado para os níveis foliares dos nutrientes, dados que corroboram os resultados desse ensaio.

Os valores apresentados estão de acordo com os indicados por Cantarella (1996) como adequados para a cultura da cana-de-açúcar nas condições do Brasil, exceto por $\mathrm{N}$ e $\mathrm{P}$, que estão levemente abaixo dos valores mencionados.

\subsection{Biometria e análises tecnológicas da cana-de-açúcar}

As medidas de comprimento, diâmetro, e massa de colmos por tratamento estão apresentadas na Tabela 12. Não houve diferença significativa entre os tratamentos.

Tabela 12. Valores médios de comprimento de colmo, diâmetro de colmos, e massa de colmos de cana-de-açúcar sob 5 tratamentos ( 1 a 5 ) de remoção de palhiço residual póscolheita.

\begin{tabular}{cccc}
\hline Tratamento & $\begin{array}{c}\text { Comprimento colmo } \\
(\mathbf{m})\end{array}$ & $\begin{array}{c}\text { Diâmetro colmo } \\
(\mathbf{m m})\end{array}$ & $\begin{array}{c}\text { Massa colmo } \\
(\mathbf{k g})\end{array}$ \\
\hline $\mathbf{1}(\mathbf{0 \%}$ palhiço) & $2,420 \mathrm{a}$ & $24,300 \mathrm{a}$ & $1,125 \mathrm{a}$ \\
$\mathbf{2}(\mathbf{2 5 \%}$ palhiço) & $2,417 \mathrm{a}$ & $25,475 \mathrm{a}$ & $1,227 \mathrm{a}$ \\
$\mathbf{3}(\mathbf{5 0 \%}$ palhiço) & $2,340 \mathrm{a}$ & $24,525 \mathrm{a}$ & $1,075 \mathrm{a}$ \\
$\mathbf{4}(\mathbf{7 5 \%}$ palhiço) & $2,350 \mathrm{a}$ & $25,150 \mathrm{a}$ & $1,227 \mathrm{a}$ \\
$\mathbf{5}(\mathbf{1 0 0 \%}$ palhiço) & $2,375 \mathrm{a}$ & $25,200 \mathrm{a}$ & $1,147 \mathrm{a}$ \\
\hline F & $1,2870 \mathrm{~ns}$ & $0,8469 \mathrm{~ns}$ & $1,2718 \mathrm{~ns}$ \\
DMS (5\%) & 0,14781 & 2,42478 & 0,26616 \\
CV $(\%)$ & 2,75 & 4,31 & 10,17 \\
\hline
\end{tabular}

Médias seguidas pela mesma letra na coluna não diferem entre si pelo teste de Tukey a 5\%.

ns Valores não significativos a $5 \%$ de probabilidade pelo teste $\mathrm{F}$.

Os resultados são similares aos encontrados por Leme Filho (2009), em estudo que avaliou o efeito do palhiço sobre diversos aspectos (dentre eles as medidas biométricas) da lavoura de cana-de-açúcar, em Piracicaba-SP, sobre Latossolo vermelho distrófico. O autor concluiu que não houve efeito positivo significativo da presença do palhiço pós-colheita nas medidas biométricas da cultura, e que a concentração do palhiço na linha de plantio prejudica o perfilhamento inicial das plantas, sendo indicado o enleiramento do palhiço nas entrelinhas.

Em contrapartida, Ceddia et al. (1999) observou efeito negativo da queima do palhiço nas medidas biométricas da cana-de-açúcar, o que não necessariamente indica malefício da remoção do palhiço por si só, mas sim da queima desse.

Os valores de fibra, Brix, pureza do caldo, e açúcares totais recuperáveis (ATR) estão apresentados na Tabela 13. 
Tabela 13. Valores médios de fibra, Brix, pureza do caldo, e açúcares totais recuperáveis (ATR) de cana-de-açúcar sob 5 tratamentos $\left(\begin{array}{ll}1 & \text { a }\end{array}\right)$ de remoção de palhiço residual póscolheita.

\begin{tabular}{ccccc}
\hline Tratamento & Fibra (\%) & ${ }^{\text {o }}$ Brix & Pza. Caldo (\%) & ATR (t.ha $\left.^{-\mathbf{1}}\right)$ \\
\hline $\mathbf{1}(\mathbf{0 \%}$ palhiço) & $11,18 \mathrm{a}$ & $16,36 \mathrm{a}$ & $86,14 \mathrm{a}$ & $13,05 \mathrm{a}$ \\
$\mathbf{2}(\mathbf{2 5 \%}$ palhiço) & $10,88 \mathrm{a}$ & $16,14 \mathrm{a}$ & $84,79 \mathrm{a}$ & $13,61 \mathrm{a}$ \\
$\mathbf{3}(\mathbf{5 0 \%}$ palhiço) & $11,18 \mathrm{a}$ & $16,18 \mathrm{a}$ & $86,43 \mathrm{a}$ & $13,73 \mathrm{a}$ \\
$\mathbf{4}(\mathbf{7 5 \%}$ palhiço) & $11,18 \mathrm{a}$ & $16,13 \mathrm{a}$ & $85,85 \mathrm{a}$ & $13,79 \mathrm{a}$ \\
$\mathbf{5 ( 1 0 0 \%}$ palhiço) & $10,88 \mathrm{a}$ & $16,04 \mathrm{a}$ & $84,00 \mathrm{a}$ & $13,64 \mathrm{a}$ \\
\hline F & $0,54 \mathrm{~ns}$ & $0,38 \mathrm{~ns}$ & $0,60 \mathrm{~ns}$ & $0,96 \mathrm{~ns}$ \\
DMS (5\%) & 1,00 & 0,84 & 5,89 & 7,87 \\
CV (\%) & 4,03 & 2,33 & 3,06 & 2,90 \\
\hline
\end{tabular}

Médias seguidas pela mesma letra na coluna não diferem entre si pelo teste de Tukey a 5\%.

ns Valores não significativos a $5 \%$ de probabilidade pelo teste $\mathrm{F}$.

Não houve diferenças significativas entre os tratamentos para os fatores das análises tecnológicas, indicando ausência de efeito do palhiço sobre a qualidade da cana-de-açúcar. Marques et al. (2014), em estudo similar, não identificou efeitos da cobertura de palhiço sobre as varáveis tecnológicas e biométricas da cana-de-açúcar. 


\subsection{Produtividade}

Os dados de produtividade (TCH) de colmos estão apresentados na Tabela 14. Não houve efeito significativo dos tratamentos sobre a produtividade da cultura.

Tabela 14. Valores médios de produtividade de colmos de cana-de-açúcar (TCH) sob 5 tratamentos (1 a 5) de remoção de palhiço residual pós-colheita.

\begin{tabular}{cc}
\hline Tratamento & $\begin{array}{c}\text { Produtividade de colmos } \\
\left(\mathbf{t ~ h a}^{-\mathbf{1}}\right)\end{array}$ \\
\hline $\mathbf{1}(\mathbf{0 \%}$ palhiço) & $113,25 \mathrm{a}$ \\
$\mathbf{2}(\mathbf{2 5 \%}$ palhiço) & $118,12 \mathrm{a}$ \\
$\mathbf{3}(\mathbf{5 0 \%}$ palhiço) & $120,00 \mathrm{a}$ \\
$\mathbf{4}(\mathbf{7 5 \%}$ palhiço) & $118,50 \mathrm{a}$ \\
$\mathbf{5}(\mathbf{1 0 0 \%}$ palhiço) & $122,50 \mathrm{a}$ \\
\hline $\mathbf{F}$ & $2,6408 \mathrm{~ns}$ \\
DMS (5\%) & 9,40635 \\
$\mathbf{C V}(\boldsymbol{\%})$ & 3,52 \\
\hline
\end{tabular}

Médias seguidas pela mesma letra na coluna não diferem entre si pelo teste de Tukey a 5\%.

ns Valores não significativos a $5 \%$ de probabilidade pelo teste $\mathrm{F}$.

Marques et al. (2014) não identificaram efeitos positivos do manejo do palhiço sobre a produtividade da cultura. Os autores observam que, apesar de identificarem outros efeitos do palhiço em seus estudos, o mesmo não ocorre para a produtividade $(\mathrm{TCH})$.

Esses resultados conflitam com os identificados por Souza et al. (2005), que identificaram efeitos positivos do palhiço sobre a qualidade (ATR) e produtividade da cultura. O autor afirma que a escarificação das entrelinhas com leve incorporação dos resíduos aumenta os efeitos observados.

É importante que se avalie os efeitos do palhiço sobre a produtividade ao longo de períodos mais amplos, dado que um dos fatores mais importantes da lavoura é a produtividade, e o conhecimento dos efeitos do palhiço sobre ela são primordiais para a tomada de decisão quanto ao manejo a ser aplicado ao palhiço. 


\section{CONCLUSÕES}

- A produtividade média de palhiço no experimento foi de 25,29 t.ha ${ }^{-1}$, e o aporte médio de material decomposto no período foi de 3,75 toneladas no tratamento 2 e 15,84 toneladas no tratamento 5 .

- O palhiço residual apresentou meia vida de 226 dias para o tratamento 2 (25\% de palhiço residual remanescente - 6,89 t.ha ${ }^{-1}$ ) e 173 dias para o tratamento 5 (100\% de palhiço residual remanescente $-25,29$ t.ha ${ }^{-1}$ ).

- Maior quantidade de palhiço residual no campo propicia decomposição e ciclagem de nutrientes mais aceleradas e menor tempo de meia vida dos resíduos.

- O palhiço é uma importante fonte de nutrientes, apresentando aporte considerável de macro e micronutrientes ao final de 270 dias (exceto $\mathrm{N}, \mathrm{Zn}$, e $\mathrm{Cu}$ ). $\mathrm{K}$ foi o nutriente proporcionalmente mais disponibilizado pelo palhiço (aproximadamente 100\%). O aporte de $\mathrm{K}$ ao final de 270 dias é suficiente para suprir a demanda da lavoura para uma produção de 100 t.ha ${ }^{-1}$ de colmos.

- Os aportes apresentados de macro e micronutrientes têm grande potencial como fonte de economia em futuras reposições de fertilizantes.

- A quantidade de palhiço remanescente não teve efeitos significativos nos níveis de macro e micro nutrientes nas folhas, nas medidas biométricas, nas análises tecnológicas, e na produtividade da cultura.

- São necessários mais estudos, preferencialmente de longo prazo, para se chegar a uma conclusão de quanto palhiço remanescente pode ser removido do campo sem afetar negativamente a cultura. 


\section{REFERÊNCIAS BIBLIOGRÁFICAS}

AMARAL, W. A. N. do; ANEX, R. P. Life cycle analysis and indicators of sustaintability of sugarcane production. In: COSER, T. R; DAVIS, M. J. (ed.). BIOFUELS: Reasonable steps towards a renewable energy future. Brasília: Fullbright Comission Brazil, 2010. p. 27-37.

ANDERSON, D.L.; BOWEN, J.E. Nutrição de Cana-de-açúcar. Piracicaba: Editora Potassa, 1992. 40p.

ANDRADE, N. S. F. DE; MARTINS FILHO, M. V.; TORRES, J. L. R.; PEREIRA, G. T.; MARQUES JÚNIOR, J. Impacto técnico e econômico das perdas de solo e nutrientes por erosão no cultivo da cana-de-açúcar. Engenharia Agrícola, Jaboticabal, v. 31, n. 3, p. 539550, jun. 2011.

ANFAVEA. Anuário da Indústria Automobilística Brasileira. São Paulo, 2010. Disponível em: http://anfavea2010.virapagina.com.br/anfavea2010/. Acesso em: 04 abr. 2015.

ARALDI, R.; SILVA, F. M. L.; ONO, E. O.; RODRIGUES, J. D. Florescimento em cana-deaçúcar. Ciência Rural. Santa Maria, v. 40, n. 3, p. 694-702, mar. 2010.

BANZATTO, D. A.; KRONKA, S. do N. Experimentação agrícola. Jaboticabal: Funep, v. 2, 2006.

BECARI, G. R. G. Resposta da cana-planta à aplicação de micronutrientes. 2010.72 p. Dissertação (Mestrado) - Instituto Agronômico, Campinas, 2010.

CAMPOS, P. F.; JÚNIOR, J. A.; SOARES, R. A. B.; RIBEIRO, P. H. P.; EVANGELISTA, A. W. P. Resposta da cultura da cana-de-açúcar à irrigação de salvamento e ao uso de palha na cobertura do solo na região do cerrado. In: CONGRESO LATINOAMERICANO y DEL CARIBE DE INGENIERÍA AGRÍCOLA, CONGRESSO BRASILEIRO DE ENGENHARIA AGRÍCOLA, 41, 2012, Londrina-PR. CLIA/CONBEA, 2012.

CANEllas, L. P.; VElloso, A. C. X.; MARCIANO, C. R.; RAMALHO, J. F. G. P.; RUMJANEK, V. M.; REZENDE, C. E.; SANTOS, G. D. A Propriedades químicas de um Cambissolo cultivado com cana-de-açúcar, com preservação do palhiço e adição de vinhaça por longo tempo. Revista Brasileira de Ciência do Solo. Viçosa, v. 27, n. 5, p. 935-944, 2003.

CANTARELLA, H. Sugarcane production. In: COSER, T. R; DAVIS, M. J. (Ed.). Biofuels: Reasonable steps towards a renewable energy future. Brasília: Fullbright Comission Brazil, 2010. p. 27-37.

CARVALHO, A. M. de Uso de plantas condicionadoras com incorporação e sem incorporação no solo: composição química e decomposição dos resíduos vegetais; 
disponibilidade de fósforo e emissão de gases. 2005. 199p. Tese de Doutorado. Universidade de Brasília, Brasília, 2005.

Carvalho, A. M. de; Souza, L. L. P. de; Guimarães Júnior, R.; Alves, P. C. A. C.; Vivaldi, L. J. Cover plants with potential use for crop-livestock integrated systems in the Cerrado region. Pesquisa Agropecuária Brasileira. Brasília, v. 46, n. 10, p. 1200-1205. 2011.

CAStro GAVA, G. J. de; TRIVElin, P. C. O.; OliVEIRA, M. W. de; PENATTI, C. P Crescimento e acúmulo de nitrogênio em cana-de-açúcar cultivada em solo coberto com palhada. Pesquisa Agropecuária Brasileira. Brasília, v. 36, n. 11, p. 1347-1354, 2001.

CEDDIA, M. B.; ANJOS, L. D.; LIMA, E.; RAVELLI NETO, A.; SILVA, L. D. Sistemas de colheita da cana-de-açúcar e alterações nas propriedades físicas de um solo Podzólico Amarelo no Estado do Espírito Santo. Pesquisa Agropecuária Brasileira. Brasília, v. 34, n. 8, p. 1467-1473, 1999.

CLAYTON, W. D.; DANIELS, C. A. Geographical, historical and cultural aspects of the origin of the indian and chinese sugarcanes $S$. barberi and $S$. sinense. Sugarcane Breeding Newsletters, [S.1.], v. 36, p. 4-23, 1975.

COELHO, M. C. Avaliação da dinâmica de decomposição da palhada de cana-de-açúcar em solo de cerrado. 2012. 40 f., Monografia (Bacharelado em Agronomia) - Faculdade de Agronomia e Medicina Veterinária, Universidade de Brasília, Brasília, 2012.

COELHO, M. C.; LIMA, W. M.; SOUZA, J. P. S. P.; DANTAS, R. A.; FONSECA, O. P.; Carvalho, A. M. de; GUIMARAES JUNIOR, R. Teores de hemiceluloses, celulose e lignina em plantas de cobertura sob manejo na floração e maturação. In: FERTIBIO 2010, 2010, Guarapari. Anais da Fertbio 2010, 2010.

CONAB. Acompanhamento da safra brasileira: cana-de-açúcar. Segundo levantamento. Agosto/2014. Disponível em: <http://www.conab.gov.br/OlalaCMS/uploads/arquivos/14_08_28_08_52_35_boletim_cana_ portugues_-_2o_lev_-_2014-15.pdf>. Acesso em: 12 jun. 2015.

CORREIA, J. R.; REATTO, A.; SPERA, S. T. Solos e suas relações com o uso e o manejo. In: SOUZA, D. M. G. de; LOBATO, G. (Ed.) Cerrado: correção do solo e adubação. 2 ed. Brasília: Embrapa Informação Tecnológica, 2004. p. 29-61.

COSTA, M. B. B.; CALEGARI, A; MIYASAKA, S.; BULISANI, E.; AMADO, T.; MONDARDO, A.; WILDNER, L.. Adubação Verde no Sul do Brasil. Rio de Janeiro: Assessoria e Serviços a Projetos em Agricultura Alternativa, v. 2000, p. 27-28, 1991.

COUTINHO, L. Aspectos do Cerrado. 2000. Disponível em: <http://eco.ib.usp.br/cerrado/index.htm>. Acessado em: mai. 2015. 
CRONQUIST, A. An integrated system of classification of flowering plants. New York: Columbia University Press, 1981. 1262 p.

DE CANA-DE, Conselho dos Produtores. Açúcar, Açúcar e Álcool do Estado de São PauloCONSECANA (2006) Manual de Instruções.

SILVA SANTANA, J. A. da; ALMEIDA VIEIRA, F. de; SILVA SOUTO, J. da; GONDIM, S. C.; FONSECA, F. D. C. E. da Decomposição da biomassa foliar de cana-de-açúcar em um Neossolo na região de Areia-PB. Revista Caatinga. Mossoró, v. 24, n. 3, p. 28-32, 2011.

DILLEWIJN, C. Botany of sugar cane. Walthen: Chronica Botanica, 1952. 359p.

DINARDO-MIRANDA, L. L.; FRACASSO, J. V. Sugarcane straw and the populations of pests and nematodes. Scientia Agricola. Piracicaba, v. 70, n. 5, p. 305-310, 2013.

EITEN, G. Vegetação do Cerrado. In: PINTO, M. N. (Ed.) Cerrado. Brasília: Editora Universidade de Brasília, 1993, p. 17-73.

EMBRAPA. Agência de informações: Bioma Cerrado. 2007. Disponível em: <http://www.cnptia.embrapa.br/Agencia16/AG01/Abertura.html>. Acesso em: jun. 2015.

EMBRAPA. Sistema brasileiro de classificação de solos. 3 ed. Brasília: Embrapa, 2013, $353 \mathrm{p}$

EMBRAPA. Zoneamento Agroecológico da Cana-de-açúcar. 2009. Disponível em: <http://www.cnps.embrapa.br/zoneamento_cana_de_acucar/1BR_ZAE_Cana.pdf $>$. Acesso em: 18 abr. 2015.

EQUIPE ESTATCAMP (2014). Software Action. Estatcamp- Consultoria em estatística e qualidade, São Carlos - SP, Brasil.

ERNANI, P.R.; ALMEIDA, J.A.; SANTOS, F.C. Potássio. In: NOVAIS, R.F.; ALVAREZ, V. H.; BARROS, N. F. de; FONTES, R. L. F.; CANTARUTTI, R. B.; NEVES, J. C. L. (ed.) Fertilidade do Solo. Viçosa: Sociedade Brasileira de Ciência do Solo, 2007. p. 551-594.

FRANCO, H. C. J.; PIMENTA, M. T. B.; CARVALHO, J. L. N.; MAGALHÃES, P. S. G.; ROSSELL, C. E. V.; BRAUNBECK, O. A.; VITTI, A. C.; KÖLLN, O. T.; ROSSI NETO, J. Assessment of sugarcane trash for agronomic and energy purposes in Brazil. Scientia Agricola. Piracicaba, v. 70, n. 5, p. 305-312. out. 2013.

FREIRE, J. de L.; DUBEUX JÚNIOR, J. C. B.; LIRA, M. de A.; FERREIRA, R. L. C.; SANTOS, M. V. F. dos,; FREITAS, E. V. de Decomposição de serrapilheira em bosque de sabiá na Zona da Mata de Pernambuco. Revista Brasileira de Zootecnia. Viçosa, v. 39, n. 8, p. 1659-1665, ago. 2010. 
GARBIATE, M. V.; VITORINO, A. C. T.; TOMASINI, B. A.; BERGAMIN, A. C.; PANACHUKI, E. Erosão em entre sulcos em área cultivada com cana crua e queimada sob colheita manual e mecanizada. Revista Brasileira de Ciências do Solo. Viçosa, v. 35, n. 6, dez. 2011.

GOEDERT, W. J. Potencial agrícola dos Cerrados. In: SIMPÓSIO SOBRE O POTENCIAL AGRÍCOLA DOS CERRADOS. Goiânia, Trabalhos apresentados. Campinas: Fundação Cargill, 1985. p. 1-2.

GRAHAM, M. H.; HAYNES, R. J.; MEYER, J. H. Soil organic matter content and quality: effects of fertilizer applications, burning and trash retention on a long-term sugarcane experiment in South Africa. Soil biology and biochemistry. v. 34, n. 1, p. 93-102. jan. 2002.

HENRIQUE, C. M.; CAMARGO, M. S. DE; FOLTRAN, D. E.; WYLER, P. Qualidade tecnológica e épocas de colheita de variedades de cana-de-açúcar cultivadas em Tietê/SP. Colloquium Agrariae, v. 7, n.1, Jan-Jun, p. 01-08, 2011.

IZIDORIO, R.; MARTINS FILHO, M V.; MARQUES JÚNIOR, J.; SOUZA, Z. M. de; PEREIRA, G. T. Perdas de nutrientes por erosão e sua distribuição espacial em área sob canade-açúcar. Engenharia Agrícola. Jaboticabal, v. 25, n. 3, dez. 2005.

JOHNSON, J. M. F.; BARBOUR, N. W.; WEYERS, S. L. Chemical composition of crop biomass impacts its decomposition. Soil Science Society of America Journal. Madison, v. 71, n. 1, p. 155-162. jan. 2007.

KLINK, C. A.; MACHADO, R. B. A conservação do Cerrado brasileiro. Megadiversidade, Belo Horizonte, v. 1, n. 1, p. 148-155, jul. 2005.

KÖPPEN, W.; GEIGER, R. Klimate der Erde. Gotha: Verlag Justus Perthes. 1928. Wallmap $150 \mathrm{~cm} \times 200 \mathrm{~cm}$.

LANDELL, M. G. A. Oxisol subsurface chemical attributes related to sugarcane productivity. Scientia Agricola. Piracicaba, v. 60, n. 4, p. 741-745, dez. 2003.

LANDELL, M. G. A.; BRESSIANI J. A. Melhoramento genético, caracterização, e manejo varietal. In: DINARDO-MIRANDA, L. L.; VASCONCELOS, A. C. M. de; LANDELL, M. G. de A. (ed.). Cana-de-açúcar. Campinas: Instituto Agronômico, 2010. p.101-155.

LANDELL, M. G. DE A.; SCARPARI, M. S.; XAVIER, M. A.; ANJOS, I. A. DOS; BAPTISTA, A. S.; AGUIAR, C. L. DE; SILVA, D. N. DA; BIDÓIA, M. A. P.; BRANCALIÃO, S. R.; BRESSIANI, J. A.; CAMPOS, M. F. DE; MIGUEL, P. E. M.; SILVA, T. N. DA; SILVA, V. H. P. DA; ANJOS, L. O. S.; OGATA, B. H. Residual biomass potential of commercial and pre-commercial sugarcane cultivars. Scientia Agricola. Piracicaba, v. 70, n. 5, p. 299-304. out. 2013. 
LAU, A. F.; CHANG, K. F.; GUNNESS, D. Additional exportable energy from bagasse. In: PROC. XXVI INT. SOC. SUGAR CANE TECHNOL. CONGRESS, Durban, South Africa. 2007.

LEME FILHO, J. R. A. Desenvolvimento da cana-de-açúcar (Saccharum spp.) sob diferentes formas de colheita e de manejo do palhiço. 2009. Tese de Doutorado. Escola Superior de Agricultura "Luiz de Queiroz", Piracicaba.

MALAVOLTA, E.; VITTI, G.C.; OLIVEIRA, S.A. Avaliação do estado nutricional das plantas: princípios e aplicações. 2.ed. Piracicaba: POTAFOS, 1997. 319p.

MARIN, F. R. Agência de Informação da Cana-de-Açúcar. Brasília: Embrapa, 2008 (Website). Disponível em: <http://www.agencia.cnptia.embrapa.br/gestor/cana-deacucar/arvore/CONTAG01_68_22122006154840.html>. Acesso em: 12 dez. 2014.

MARQUES, T. A.; JUNIOR, E. L. D.; RAMPAZO, É. M.; MARQUES, P. A. A. Palhiço, polímero hidrogel e sistemas de plantio nos parâmetros de biometria, tecnologia, energia e produtividade de cana-de-açúcar. Bioscience Journal. Uberlândia, v. 30, n. 5, 2014.

MARTIN, J. P. The anatomy of the sugar cane plant. In: MARTIN, J. P.; ABBOT, E. V.; HUGHES, C. G. (Ed.) Sugar-cane diseases of the world. Amsterdam: Elsevier, 1961. p. 152.

MELLIS, E. V., QUAGGIO, J. A., CANTARELLA, H. Micronutrientes. In: DINARDOMIRANDA, L. L.; VASCONCELOS, A. C. M.DE; LANDELL, M. G. de A. (ed.). Cana-deaçúcar. Campinas: Instituto Agronômico, 2010. p.331-337.

MENEGUELlo, L. A.; CASTRO, M. C. A. A. O protocolo de Kyoto e a geração de energia elétrica pela biomassa da cana-de-açúcar como Mecanismo de desenvolvimento Limpo. Revista Internacional de Desenvolvimento Local. Campo Grande, v. 8, p. 33-45, 2007.

NOVAIS, R. F.; SMYTH, T. J.; NUNES, F. N. Fósforo In: NOVAIS, R.F.; ALVAREZ, V. H.; BARROS, N. F. de; FONTES, R. L. F.; CANTARUTTI, R. B.; NEVES, J. C. L. (ed.) Fertilidade do Solo. Viçosa: Sociedade Brasileira de Ciência do Solo, 2007. p. 471-550.

ORLANDO FILHO, J. Calagem e adubação da cana-de-açúcar. In: CÂMARA, G.M.S.; OLIVEIRA, E.A.M. (Ed.) Produção de cana-de-açúcar. Piracicaba: FEALQ, 1993. p.13346.

ORLANDO FILHO, J.; ROSSETO, R.; CASAGRANDE, A.A. Cana-de-açúcar. In: FERREIRA, M.E.; CRUZ, M.C.P. RAIJ, B. ABREU, C.A. (ed.). Micronutrientes e elementos tóxicos na agricultura. Jaboticabal: CNPq/FAPESP/POTAFOS, p. 355-369, 2001. 
PICOLI, M. C. A.; RUDORFF, B. F. T.; RIZZI, R.; GIAROLLA, A. Índice de vegetação do sensor MODIS na estimativa da produtividade agrícola da cana-de-açúcar. Bragantia, Campinas, v. 68, n. 3, p. 789-795, set. 2009.

PRADO, H.; PÁDUA JÚNIOR, A. L.; GARCIA, J. L.; MORAES, J. F. L. de; CARVALHO, J. P. de; DONZELI, P. L. Solos e ambientes de produção. In: DINARDO-MIRANDA, L. L.; VASCONCELOS, A. C. M.DE; LANDELL, M. G. de A. (ed.). Cana-de-açúcar. Campinas: Instituto Agronômico, 1 ed., 2010. p.179-204.

PRADO, R. de M.; PANCELLI, M. A. Resposta de soqueiras de cana-de-açúcar à aplicação de nitrogênio em sistema de colheita sem queima. Bragantia, Campinas , v. 67, n. 4, p. 951959. dez. 2008

QUAGgIO, J. A. Acidez e Calagem em Solos Tropicais. 1 ed. Campinas: Instituto Agronômico, 2000. 111 p.

QUAGGIO, J. A.; van RAIJ, B. Cálcio, magnésio e correção da acidez do solo. In: DINARDO-MIRANDA, L. L.; VASCONCELOS, A. C. M.DE; LANDELL, M. G. de A. (ed.). Cana-de-açúcar. Campinas: Instituto Agronômico, 2010. p.313-322

RAIJ, B. van; CANTARELLA, H. Outras culturas industriais. In: RAIJ, B. van; CANTARELlA, H.; QUAGGIO, J.A.; FURLANI, A.M.C. (Ed.) Recomendações de adubação e calagem para o Estado de São Paulo. Campinas: IAC, 2 ed., 1997. p.233-236. (Boletim Técnico, 100).

RANGEL, L. C.; VIEIRA, J. R.; SILVA LOPES, R. da Cogeração e comercialização de excedentes de eletricidade em uma usina sucroalcooleira. PerspectivasOnLine 2007-2010, v. 4, n. 13, 2014.

REATTO, A.; CORREIA, J. R.; SPERA, S. T. Solos do Bioma Cerrado: aspectos pedológicos. In: SANO, S. M.; ALMEIDA, S. P. (Ed.) Cerrado: ambiente e flora. Planaltina: EMBRAPA-CPAC, 1998. p. 47-83.

RIBEIRO, H.; PESQUERO, C. Queimadas de cana-de-açúcar: Avaliação de efeitos na qualidade do ar e na saúde respiratória de crianças. Estudos Avançados. São Paulo, v.24, n.68, 2010 .

RIPOLI, T. C. C.; RIPOLI M. L. C. Biomassa de cana-de-açúcar: colheita, energia e ambiente. Piracicaba: edição dos autores, 2004. 302 p.

RIPOLI, T. C. C.; RIPOLI M. L. C. Biomassa de cana-de-açúcar: colheita, energia e ambiente. Piracicaba: edição dos autores, 2004. 302 p.

RIPOLI, T. C. C.; Ripoli, M. L. C. Bioenergia, Açúcar e Álcool - Tecnologias e Perspectivas In: SANTOS, F.; BORÉM, A.; CALDAS, C. (ed.) Cana-de-Açúcar. Viçosa: Ed. da UFV, 2010, cap. 10. 
ROSSETTO, R.; DIAS, F. L. F.; VITTI, A. C.; PRADO JÚNIOR, J. P. Q. Fósforo In: DINARDO MIRANDA, L. L.; VASCONCELOS, A. C. M. de; LANDELL, M. G. de A. (ed.) Cana-de-açúcar. Campinas: Instituto Agronômico, 1 ed., 2010. p. 271-288.

ROSSETTO, R.; DIAS, F. L. F.; VITTI, A. C.; TAVARES, S. Potássio In: DINARDO MIRANDA, L. L.; VASCONCELOS, A. C. M. de; LANDELL, M. G. de A. (ed.) Cana-deaçúcar. Campinas: Instituto Agronômico, 1 ed., 2010. p. 289-312.

SANTOS, P. F.; WHITFORD, W. G. The effects of microarthropods on litter decomposition in a Chihuahuan desert ecosystem Ecology, p. 654-663, 1981.

SCARPARI, M. S.; BEAUCLAIR, E. G. F. de. Anatomia e botânica. In: DINARDOMIRANDA, L. L.; VASCONCELOS, A. C. M. DE; LANDELL, M. G. de A. (Ed.) Cana-deaçúcar. Campinas: Instituto Agronômico, 1 ed., 2010. p. 45-56.

SILVA, D.; QUEIROZ, A. C. de. Análise de alimentos:(métodos químicos e biológicos). UFV, Impr. Univ., 1981.

SILVA, F. A. S. Assistat versão 7.6 beta. Assistência estatística. Registro INPI: 0004051-2. Atualizada em: 05/03/2012. DEACG-CTRN-UFCG, Campina Grande-PB, Brasil. Disponível em:<www. assistat. com>. Acesso em: 01 de dez, 2014.

SILVA, I. R.; MENDONÇA, E. S. Matéria orgânica do solo. In: NOVAIS, R.F.; ALVAREZ, V. H.; BARROS, N. F. de; FONTES, R. L. F.; CANTARUTTI, R. B.; NEVES, J. C. L. (ed.) Fertilidade do solo. Viçosa: Sociedade Brasileira de Ciência do Solo, 2007. p.275-374.

SOUSA, D. M. G.; MIRANDA, L. N.; OLIVEIRA, S. A. Acidez do solo e sua correção. In: NOVAIS, R.F.; ALVAREZ, V. H.; BARROS, N. F. de; FONTES, R. L. F.; CANTARUTTI, R. B.; NEVES, J. C. L. (ed.) Fertilidade do solo. Viçosa: Sociedade Brasileira de Ciência do Solo, 2007. p.205-274.

SOUSA, G. B.; MARTINS FILHO, M. V.; MATIAS, S. S. R.. Perdas de solo, matéria orgânica e nutrientes por erosão hídrica em uma vertente coberta com diferentes quantidades de palha de cana-de-açúcar em Guariba - SP. Engenharia Agrícola, Jaboticabal, v. 32, n. 3, p. 490-500, jun. 2012.

SOUZA, Z. M. de; PRADO, R. de M.; PAIXÃO, A. C. S.; CESARIN, L. G. Sistemas de colheita e manejo da palhada de cana-de-açúcar. Pesquisa Agropecuária Brasileira, v.40, p.271-278, 2005.

SPERA, S. T.; CORREIA, J. R.; REATTO, A. Solos do Bioma Cerrado: propriedades químicas e físico-hídricas sob uso e manejo de adubos verdes. In: CARVALHO, A. M. de; AMABILE, R. F. (Ed.) Cerrado: adubação verde. Planaltina: Embrapa Cerrados, 2006. p. 23-40.

TAIZ, L.; ZEIGER, E. Fisiologia vegetal. Porto Alegre: Artmed, 2004. 954 p. 
TRIVELIN, P. C. O.; FRANCO, H. C. J.; OTTO, R.; FERREIRA, D. A.; VITTI, A. C.; FORTES, C.; FARONI, C. E.; OLIVEIRA, E. C. A.; CANTARELLA, H. Impact of sugarcane trash on fertilizer requirements for São Paulo, Brazil. Scientia Agricola. Piracicaba, v. 70, n. 5, p. 345-352. out. 2013.

USINA pioneira de etanol celulósico coloca Brasil entre líderes globais no uso da nova tecnologia. Disponível em: <http://www.unica.com.br/noticia/29810917920343378786/usinapioneira-de-etanol-celulosico-coloca-brasil/> . Acesso em: 18 mai. 2015.

VALE, D.; PRADO, R.; AVALHÃES, C.; HOJO, R. Omissão de macronutrientes na nutrição e no crescimento da cana-de-açúcar cultivada em solução nutritiva. Revista Brasileira de Ciências Agrárias. Recife, v. 6, n. 2, p. 189-196. abr.-jun. 2011.

VASCONCELOS, A. C. M. Desenvolvimento do sistema radicular da parte aérea de socas de cana-de-açúcar sob dois sistemas de colheita: crua mecanizada e queimada manual. 2002. 140p. Tese (Doutorado) - Universidade Estadual Paulista, Jaboticabal.

VITTI, A. C.; CANTARELlA, H.; TRIVELIN, P. C. O.; BOLOGNA-CAMPBELL, I. Enxofre. In: DINARDO-MIRANDA, L. L.; VASCONCELOS, A. C. M.DE; LANDELL, M. G. de A. (ed.). Cana-de-açúcar. Campinas: Instituto Agronômico, 2010. p.323-330.

VITTI, A. C.; CANTARELlA, H.; TRIVELIN, P. C. O.; ROSSETO, R. Nitrogênio. In: DINARDO-MIRANDA, L. L.; VASCONCELOS, A. C. M.DE; LANDELL, M. G. de A. (ed.) Cana-de-açúcar. Campinas: Instituto Agronômico, 1 ed., 2010. p. 239-270. 